\title{
Postharvest Applications of 1-Methylcyclopropene and Salicylic Acid for Maintaining Quality and Enhancing Antioxidant Enzyme Activity of Apricot Fruits cv. 'Canino' During Cold Storage
}

\author{
U.K. El-Abbasy, A.F. Abd El-Khalek and M.I. Mohamed \\ Horticulture Department, Faculty of Agriculture, Tanta University, 31527. Egypt.
}

\begin{abstract}
A PRICOT is one of a fragile and climacteric fruit that ripens very quickly after harvest resulting in very short storage life. 1-Methylcyclopropene (1-MCP) and salicylic acid (SA) are widely used because it inhibits the action of ethylene receptors. The objective of this experiment was to evaluate the effect of pre-storage application with either 1-MCP or SA immediately after harvest on quality, storability and shelf life of apricot fruits cv. 'Canino' during the two seasons 2015 and 2016. Apricot fruits divided into three equal groups and exposed to $1-\mathrm{MCP}$ at $0,0.5$ or $1 \mathrm{ppm}$ for 24 hours at room temperature $(\sim 25)$. After the duration of 1-MCP treatments, the fruits divided into three equal subgroups and the apricot fruits in each subgroup were dipped into aqueous solutions of SA at $0,0.5$ or $1 \mathrm{mM}$ concentration for five minutes. All treatments of 'Canino' apricot fruits stored at $0 \pm 1^{\circ} \mathrm{C}$ and $90 \pm 5 \%$ relative humidity for 28 days followed by 3 days shelf life at $\sim 25$ as a simulation marketing period. The changes in physical and chemical properties as well as the activities of antioxidant and cell wall hydrolytic enzymes of apricot fruits were determined at weekly intervals throughout the cold storage period at $0^{\circ} \mathrm{C}$ as well as after end of cold storage plus 3 days shelf life at 25. All pre-storage studied treatments of 'Canino' apricot fruits significantly improved fruit quality characteristics than control treatment during cold storage and shelf life. Combinations treatments of $1-\mathrm{MCP}$ at 0.5 or $1 \mathrm{ppm}$ plus SA at 0.5 or $1 \mathrm{mM}$ were superior to $1-\mathrm{MCP}$ or SA alone. Canino apricots fruits treated with the combinations of exposure to $0.5 \mathrm{ppm}$ of $1-\mathrm{MCP}$ plus 0.5 or $1 \mathrm{mM}$ SA dipping had less weight loss and decay percentage with higher marketable fruit percentage and fruit firmness. In addition, these treatments had the lowest deterioration rate in titratable acidity (TA) and ascorbic acid contents as well as slowed the increase in total soluble solids (TSS) content and TSS/TA ratio. Moreover, these treatments delayed fruit colour development, increased fruit total phenolic content and reduced the activity of pectin methylesterase (PME) enzyme as well as enhanced the activities of antioxidant enzymes of superoxide dismutase (SOD), catalase (CAT) and peroxidase (POX) as compared to the other treated and untreated (control) apricot fruits.
\end{abstract}

Keywords: 'Canino' apricot, 1-Methylcyclopropene, Salicylic acid, Ripening, Fruit quality, Pectin methylesterase, Antioxidant enzymes.

\section{Introduction}

Apricot (Prunus armeniaca L.) is one of the most important and popular fruit species around the world because of their high nutritional value, antioxidant and aroma (Solis-Solis et al., 2007). It is one of the most popular fruits to the Egyptian consumers. In Egypt, the total apricot planted area reached 69236 feddans, while the apricot planted fruiting area reached 65568 feddans produced nearly 330791 tons (Anonymous, 2014). Apricot is a climacteric fruits that produces large amounts of ethylene at the ripening (Mita et al., 1999). It starts to lose its physical and chemical qualities directly after harvest and through the storage period (Ezzat et al., 2012). Fruit temperature reduction used to control bruising injury and to delay ripening process in apricots (De Martino et al., 2002). Unfortunately, the use of low temperature on apricots very often inhibits aroma development especially in early harvested fruits (Botondi et al., 1999) and show some physiological disorders such as mealiness development, losses of juiciness and gel breakdown (Stanley et al., 2010 and Ezzat et al., 2012). Fruit ripening and senescence may be 
regarded as an oxidative process involving marked alterations in fruit metabolism and the activity of some enzymatic systems including those related to the regulation of reactive oxidative species and the deleterious effects of ethylene have been linked with reactive oxygen species detoxifying enzymes (Masia, 1998).

In postharvest management practices, chemicals used to delay fruit ripening of various climacteric fruits by stimulation or inhibition of ethylene production. 1-Methylcyclopropene (1MCP) $\left(\mathrm{C}_{4} \mathrm{H}_{6}\right)$ is an inhibitor of ethylene action that blocks ethylene receptors (Sisler and Serek, 1997; Dong et al., 2002 and Sisler, 2006). It is a cyclic olefin that inhibition ripening process by occupying irreversibly ethylene binding sites, so that ethylene is unable to bind and elicit subsequent signal transduction and translation (Blankenship and Dole, 2003). Application of 1-MCP at low concentrations prior to the climacteric increase delayed the onset of the climacteric peaks of carbon dioxide and ethylene production by reducing the activities of ethylene biosynthesis enzymes (Blankenship and Dole, 2003). Exposure 'Longyan Mei' apricot fruits to $500 \mu \mathrm{L} / \mathrm{L}$ of 1-MCP application for 24 hours inhibited the browning index and prolonged the storage period for 30 days at $10^{\circ} \mathrm{C}$ by enhancing the activities of antioxidant enzyme of SOD, POX and CAT (Shi et al., 2013). 1-MCP applications used for delaying ripening process, improving postharvest quality and extending fruit storage life for many fruits including, apricots (Fan et al., 2000; Dong et al., 2002; Valero et al., 2005 and Egea et al., 2010), plums (Erkan and Eski, 2012), peaches (Liu et al., 2005 and Jin et al., 2011), nectarines (Özkaya et al., 2016) and mangoes (Mohamed et al., 2016b).

Salicylic acid (SA) is a natural, safe simple phenolic compound and recognized as a plant growth regulator that regulates many processes in plants. SA is an important component in the signal transduction pathway (Raskin, 1992). SA treatment was counteracted the negative effects of reactive oxygen species by increasing antioxidant enzymes activity (Wang et al., 2006; Tareen et al., 2012b; Ali et al., 2014 and Ezzat, 2014). SA treatment has reported to delay ripening on different climacteric fruits by inhibiting ethylene biosynthesis and maintain postharvest quality of horticultural crops (Asghari and Aghdam, 2010). Postharvest application of SA prolonged the storage life and preserved the valuable marketing characteristics of 'Asgar-Abad' apricots (Hajilou

Egypt. J. Hort. Vol. 45, No.1 (2018) and Fakhimrezaei, 2013). In addition, dipping apricots in $2 \mathrm{mM} \mathrm{SA}$ for 15 minutes (min) significantly reduced the decay development with maintaining fruit quality during cold storage at $1^{\circ} \mathrm{C}$ for 28 days (Ezzat, 2014). Furthermore, immersed apricots in $0.5 \mathrm{mM}$ SA solutions for 3 min plus covered with cellophane film significantly improved fruit quality and extended fruit shelf life after 3 weeks of cold storage at $0.5^{\circ} \mathrm{C}$ (Moradinezhad and Jahani, 2016). Postharvest application dipping in $2 \mathrm{mM}$ of SA for $3 \mathrm{~min}$ extend apricots fruits shelf by slowing down ripening process, enhancing antioxidant activity and retaining fruits quality (Ali et al., 2013 and Ali et al., 2014). Pre-storage dipping of SA at $1 \mathrm{mM}$ doses delayed decay incidence and maintained peach fruit quality during cold storage at $0^{\circ} \mathrm{C}$ for 28 days and subsequently 3 days shelf life at $25^{\circ} \mathrm{C}$ (Wang et al., 2006). Similarly, 'Flordaking' peach fruits treated with $2 \mathrm{mM}$ concentration of SA delaying fruit surface decay and keeping fruit quality intact along during storage at $0^{\circ} \mathrm{C}$ up to five weeks (Tareen et al., 2012a, b). Furthermore, SA treatments prolonged the storage life by maintaining nutritional attributes and shown good results in controlling fungal disease, stimulated antioxidant enzymes and delayed ripening and senescence mechanisms during postharvest storage of sweet cherries (Valero et al., 2011). Moreover, SA treatment found to delay banana fruits ripening process by decreasing the activities of cell wall degrading enzymes (Srivastava and Dwivedi, 2000).

Therefore, the present study was designed to investigate the effect of pre-storage applications of exposure to 1-MCP, SA dipping and coapplications on postharvest quality, antioxidant enzyme activity and cell wall hydrolytic enzyme activity of apricot fruits cv. 'Canino' during cold storage at $0 \pm 1{ }^{\circ} \mathrm{C}$ and $90 \pm 5 \%$ relative humidity (RH).

\section{Materials and Methods}

Fruit materials and treatments

The present investigation was conducted during two successive seasons 2015 and 2016 at Horticulture Department, Faculty of Agriculture, Tanta University, Egypt. Apricot fruits cv. 'Canino' were picked at commercial maturity stage (yellowish green) according to DragovicUzelac et al. (2007) during the $2^{\text {nd }}$ week of June. Trees were similar apparently uniform in size and free of visible symptoms of infection grown in a private orchard in Wadi El-Molak, Ismailia 
Governorate, Egypt (latitude, $30^{\circ} 36^{\prime} \mathrm{N}$, longitude, $32^{\circ} 14^{\prime}$ E). Cainno apricot trees were 10 years old and planted at a spacing of $5 \times 6$ meters apart in a sandy soil under drip irrigation system and subjected to all ideal agriculture practices. In both experimental seasons, fruits were brought to the Horticulture laboratory through 2 hours at ambient temperature $\left(\sim 30^{\circ} \mathrm{C}\right)$ after harvesting in plastic boxes $(15 \mathrm{~kg}$ capacity). Fruits were cleaned, sorted, graded and the detective fruits including wounded and other disorders were excluded. The sound fruits at the same maturity stage were washed with $0.01 \%$ sodium hypochlorite water solution for $2 \mathrm{~min}$ to clean the surface of fruits and completely air dried at room temperature. A 2025 clean sound 'Canino' apricot fruits were randomly selected and divided into three equal groups. All groups were exposed to $0,0.5$ or $1 \mathrm{ppm}$ of $1-\mathrm{MCP}$ concentrations for 24 hours at room temperature $\left(25 \pm 3^{\circ} \mathrm{C}\right.$ and $\left.65 \pm 5 \% \mathrm{RH}\right)$. A powder containing $0.14 \%$ of $1-\mathrm{MCP}$ as active ingredient was released from a commercial powdered formulation (Smart Fresh $^{\mathrm{TM}}$ Rohm and Hass Inc., USA) by adding distilled water, according to the manufacturer's instructions.

After the duration of 1-MCP treatments, the fruits in each group were removed and divided into three subgroups. The fruits in each subgroup were dipped into aqueous solutions of SA at $0,0.5$ or $1 \mathrm{mM}$ concentration for $5 \mathrm{~min}$ in five liter of an aqueous solution containing Tween- $800.05 \%$ $(\mathrm{v} / \mathrm{v})$. After immersing treatments, fruits were air dried for half hour at room temperature and placed into unsealed netted plastic bags $30 \mathrm{~cm}$ deep x 20 $\mathrm{cm}$ wide. Each treatment consisted of 15 bags with three replicates and each replicate contained of 15 fruits for each storage period. All treatments packed in corrugated cartons with dimensions of $45 \times 35 \times 10 \mathrm{~cm}$ and experimental boxes were stored at $0 \pm 1{ }^{\circ} \mathrm{C}$ and $90 \pm 5 \%$ RH. Data was recorded on physical and chemical characteristics at the picking date (zero time of cold storage), and repeated at weekly intervals during cold storage period. After end of cold storage period (28 days at $0^{\circ} \mathrm{C}$ ) three bags of each treatment were moved to room conditions $\left(25 \pm 3^{\circ} \mathrm{C}\right.$ and $\left.65 \pm 5 \% \mathrm{RH}\right)$ for three days as a simulation-marketing period for determining different quality attributes.

Measurements of fruit weight loss, decay, marketable and fruit firmness

Weight loss percentage of fruits was calculated by the following formula: [(fruit weight before storage - fruit weight after each period of storage) / (fruit weight before storage) $] \times 100$.
Decay incidence was recorded every week by the number of decayed fruits due to browning, fungus and any micro-organisms infection and decay incidence of fruits was calculated as a percentage of the initial number of stored fruits using the following equation: (number of decayed fruits after special storage period / initial number of stored fruits) $\times 100$.

Marketable percentage was calculated by the following formula: (weight of sound fruits after special storage period / initial weight of fruits) $\times$ 100.

Fruit firmness in flesh was measured in three apricot fruits per replication at two equatorial sites to determine the penetration force by using a hand-held fruit firmness tester (Model FT-327, Italy) equipped with an $8 \mathrm{~mm}$ cylindrical stainless steel plunger tip (Watkins and Harman, 1981). Two readings were taken on the flesh of each fruit after peeling. The firmness value was expressed in terms of kilogram force (kgf) and data was calculated as Newton $(\mathrm{N})$ by the following formula $(1 \mathrm{~N}=0.1 \mathrm{kgf})$.

Measurements of ascorbic acid (AsA), total soluble solids (TSS), titratable acidity (TA) contents and TSS/TA ratio

The fruit juice was extracted by crushing the pulp of apricots, then strained through a muslin cloth and used for measuring AsA, TSS, TA contents and TSS/TA ratio

AsA was determined according to AOAC (2000). Samples of fruit juice were used, oxalic acid solution was added to each sample and titrated with 2,6-dichlorophenol-indophenol dye solution and expressed as a milligram of AsA and was calculated as $\mathrm{mg} / 100 \mathrm{ml}$ of the juice.

TSS content was measured using a hand refractometer, 0-32 scale (ATAGO N-1 Japan) and expressed in ${ }^{\circ}$ Brix after making the temperature correction at $20^{\circ} \mathrm{C}$ according to AOAC (2000).

TA was assayed based on the method of adopting the procedure described by AOAC (2000). Aliquot of fruit juice was taken and titrated against $0.1 \mathrm{~N} \mathrm{NaOH}$ in the presence of phenolphthalein as an indicator to the end point and was calculated as grams of malic acid per 100 $\mathrm{ml}$ of juice.

TSS/TA ratio was calculated from the values recorded for fruit juice TSS and TA percentages were determined.

Egypt. J. Hort. Vol. 45, No.1 (2018) 


\section{Measurement of fruit pigments}

Chlorophyll and carotenoids contents in pulp of apricots (three replicates) were spectrophotometrically determined according to the method of Wettestein (1957). The absorbance of the extract was measured at a spectrum of $662 \mathrm{~nm}$ for chlorophyll $a, 644 \mathrm{~nm}$ for chlorophyll $b$ and 440 for carotenoids by using a spectrophotometer (UV-Vis spectrophotometer UV 9100 B. LabTech). Pigment contents were calculated according to Wettestein (1957) by the following equations:

Chlorophyll $a=\left(9.784 \times \mathrm{E}_{662}\right)-\left(0.99 \times \mathrm{E}_{644}\right)=$ $\mu \mathrm{g} / \mathrm{ml}$

Chlorophyll $b=\left(21.426 \times \mathrm{E}_{644}\right)-\left(4.65 \times \mathrm{E}_{662}\right)$ $=\mu \mathrm{g} / \mathrm{ml}$

Total chlorophyll $=$ chlorophyll $a+$ chlorophyll $b=\mu \mathrm{g} / \mathrm{ml}$

Total carotenoids $=\left(4.695 \times \mathrm{E}_{440}\right)-(0.268 \times$ sum of chlorophyll $a$ and $b)=\mu \mathrm{g} / \mathrm{ml}$

Where $\mathrm{E}=$ Optical density at the indicated spectrum length and results were expressed as $\mathrm{mg} / 100$ gram of fresh weight (g FW) by the following formula: [(Resulting value from each equation $\times$ volume extract $) /(1000 \times \mathrm{FW})] \times 100$.

\section{Determination of total phenolic content}

Total phenolic content in pulp of apricots with three replicates was spectrophotometrically determined by the Folin-Ciocalteu method according to Slinkard and Singleton (1977). The absorbance against distilled water as a blank was determined at $765 \mathrm{~nm}$ by using a spectrophotometer (UV-Vis spectrophotometer UV 9100 B. LabTech). Total phenolic content was calculated from a standard curve obtained from different concentrations of gallic acid and expressed as mg of gallic acid equivalents/100 g FW.

\section{Enzymes specific activities assessment}

Antioxidant enzyme specific activities were determined in fruit samples that collected at 0,7 , 14,21 and 28 days during cold storage at $0^{\circ} \mathrm{C}$ and after the end of cold storage period ( 28 days) plus three days shelf life at about $25^{\circ} \mathrm{C}$. Soluble protein contents of the enzyme extract were assayed according to the method of Bradford (1976) using bovine serum albumin as a standard. Five grams of frozen apricot pulp of ten fruits from triplicate samples of each treatment were homogenized using a chilled pestle and mortar with $5 \mathrm{ml}$ of $0.05 \mathrm{M}$ potassium phosphate buffer $(\mathrm{pH}=7.8)$ containing $1 \mathrm{M} \mathrm{KCl}, 0.5 \%$ polyvinylpyrrolidone, $0.1 \mathrm{mM}$ EDTA and $2 \mathrm{mM}$ dithiothreitol. The

Egypt. J. Hort. Vol. 45, No.1 (2018) homogenate apricot pulp was filtered through four layers of cheesecloth. The extract was centrifuged at $20000 \mathrm{~g}$ at $4^{\circ} \mathrm{C}$ for $15 \mathrm{~min}$. The obtained supernatant was used as an enzyme extract to determine superoxide dismutase (SOD), catalase (CAT), peroxidase (POX) and pectin methylesterase (PME) specific activities.

SOD (EC 1.15.1.1.) activity was assayed by measuring its ability to inhibit the photochemical reduction of nitroblue tetrazolium (NBT) adopting the method of Giannopolities and Ries (1977). SOD was measured by using a spectrophotometer (UV-Vis spectrophotometer UV 9100 B. LabTech) at $560 \mathrm{~nm}$ and one unit of SOD activity was defined as the amount of enzyme required to cause $50 \%$ inhibition of NBT under the experimental conditions and the specific activity of SOD enzyme was expressed as units $\mathrm{mg}^{-1}$ protein.

CAT (EC 1. 11. 1.6) specific activity was measured spectrophotometrically as described by Clairbone (1985). The degradation of $\mathrm{H}_{2} \mathrm{O}_{2}$ was measured by the decrease in absorbance at $240 \mathrm{~nm}$ by using a spectrophotometer (UV-Vis spectrophotometer UV 9100 B. LabTech). The molar extinction coefficient of $\mathrm{H}_{2} \mathrm{O}_{2}$ at $240 \mathrm{~nm}$ was taken as $40 \mathrm{mM}^{-1} \mathrm{~cm}^{-1}$. One unit of enzyme activity was defined as amount of enzyme catalyzing the decomposition of one $\mu \mathrm{mol} \mathrm{H}_{2} \mathrm{O}_{2}$ per minute and specific activity of CAT enzyme was expressed as $\mu \mathrm{mol} \mathrm{min}^{-1} \mathrm{mg}^{-1}$ protein.

POX (EC 1. 11. 1.7) specific activity was performed using guaiacol as a donor and $\mathrm{H}_{2} \mathrm{O}_{2}$ as a substrate according to the method of Herzog and Fahimi (1973). The assay mixture $(100 \mathrm{ml})$ contained $10 \mathrm{ml}$ of $1 \%(\mathrm{v} / \mathrm{v})$ guaiacol, $10 \mathrm{ml}$ of 0.3 $\% \mathrm{H}_{2} \mathrm{O}_{2}$ and $80 \mathrm{ml}$ of $50 \mathrm{mM}$ sodium phosphate buffer solution $(\mathrm{pH}=6.6)$. Volume of $0.1 \mathrm{ml}$ of crude enzyme was added to $2.9 \mathrm{ml}$ of the assay mixture to start the reaction. The increasing absorbance was recorded every $30 \mathrm{sec}$ for $3 \mathrm{~min}$ at $470 \mathrm{~nm}$ by using a spectrophotometer (UV-Vis spectrophotometer UV 9100 B. LabTech). One unit of POX activity was defined as the amount of enzyme that caused an increase in absorbance of optical density at $460 \mathrm{~nm}$ per min under the assay conditions and the specific activity was expressed

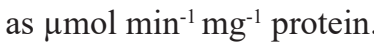

PME (EC 3.1.1.11) specific activity was extracted and assayed by the method of Hagerman and Austin (1986) with some modification. The activity was assayed in a mixture containing 2 $\mathrm{ml}$ of citrus pectin solution $(0.01 \%), 0.2 \mathrm{ml} \mathrm{NaCl}$ 
$(0.15 \mathrm{M}), 0.1 \mathrm{ml}$ of bromothymol blue solution $(0.01 \%), 0.6 \mathrm{ml}$ of distilled water and $0.1 \mathrm{ml}$ of enzymatic extract. All solutions (pectin, indicator dye and distilled water) were adjusted to $\mathrm{pH}$ 7.5 using $0.1 \mathrm{~N} \mathrm{NaOH}$ just before each trial was started. After adding the prepared enzyme, the cuvette was gently shaken. The absorbance was measured immediately at $620 \mathrm{~nm}$ by using a spectrophotometer (UV-Vis spectrophotometer UV 9100 B. Lab Tech) and measured again after 3 min. The different values in absorbance between 0 and $3 \mathrm{~min}$ were the measure of PME activity. An activity calculation was conducted by using a standard curve as described by Hangermann and Austin (1986). One unit was defined as the amount of enzyme required for liberating one $\mu \mathrm{mol}$ of methyl ester $\mathrm{min}^{-1} \mathrm{mg}^{-1}$ protein.

\section{Experimental design and statistical data analysis}

This experiment was arranged in a completely randomized design having three replications. The experimental in cold storage consisting of two factors (pre-storage treatments and storage periods) and analysis as factorial, while in shelf life consisting of one factor that is pre-storage treatments. Data calculated as percentage were transformed to arcsine of square root before statistical analysis and non-transformed means are shown. The effects of treatments and cold storage periods on different attributes were analyzed statistically by analysis of variance (ANOVA) using the MSTAT-C statistical package (M-STAT, 1993). Comparisons between means in cold storage or shelf life were done by Duncan's multiple range tests (DMRT) at probability $\leq 0.05$.

\section{Results and Discussion}

Effect of pre-storage application with exposure to 1-methylcyclopropene (1-MCP), salicylic acid (SA) dipping and their combinations on physical and chemical characteristics of 'Canino' apricot fruits during cold storage and shelf life

Fruit weight loss, decay incidence, marketable percentage and firmness

Data shown in Tables 1, 2, 3 and 4 reveal that, exposure of 'Canino' apricots to 0.5 or $1 \mathrm{ppm}$ of 1 -MCP or dipping in SA at 0.5 or 1 $\mathrm{mM}$ concentration significantly decreased fruit weight loss and decay percentage especially their combination treatments. On contrast, these treatments significantly increased marketable fruit percentage and flesh firmness in comparison with control fruits during the two seasons in this study. However, non-significant differences were observed among individual treatments and also among co-applications of fruit decay and marketable percentages in both seasons under this experiment. Data also cleared that, combined treatment with 1-MCP and SA delayed the decay incidence of apricots up to 21 days of cold storage at $0^{\circ} \mathrm{C}$ in both seasons under this study.

TABLE 1. Changes in weight loss percentage of 'Canino' apricots treated with exposure to 1-methylcyclopropene (1-MCP) application, salicylic acid (SA) dipping and their combined treatments during cold storage at $0^{\circ} \mathrm{C}$ for 28 days

\begin{tabular}{|c|c|c|c|c|c|c|c|c|c|}
\hline \multirow{3}{*}{ Pre-storage treatments } & \multicolumn{8}{|c|}{ Storage period (days) } & \multirow{3}{*}{ Means } \\
\hline & $\mathbf{0}$ & & 7 & & 14 & 21 & & 28 & \\
\hline & \multicolumn{8}{|c|}{ Season 2015} & \\
\hline Distilled water (control) & $0.00 \mathrm{~s}$ & 11.86 & def & 16.34 & $\mathrm{c}$ & $21.54 \mathrm{~b}$ & 26.37 & $\mathrm{a}$ & $15.22 \mathrm{~A}$ \\
\hline $0.5 \mathrm{ppm} 1-\mathrm{MCP}$ & $0.00 \mathrm{~s}$ & 6.40 & mno & 9.59 & $g-j$ & $11.50 \mathrm{def}$ & 12.73 & $\mathrm{~d}$ & $8.05 \mathrm{~B}$ \\
\hline 1 ppm 1-MCP & $0.00 \mathrm{~s}$ & 6.60 & mno & 9.63 & $\mathrm{~g}-\mathrm{j}$ & 11.32 def & 12.61 & de & 8.03 \\
\hline $0.5 \mathrm{mM} \mathrm{SA}$ & $0.00 \mathrm{~s}$ & 5.24 & o-r & 8.90 & $\mathrm{jk}$ & $10.58 \mathrm{fgh}$ & 11.94 & def & 7.33 \\
\hline $1 \mathrm{mM}$ SA & $0.00 \mathrm{~s}$ & 5.60 & opq & 8.57 & $\mathrm{jkl}$ & $10.43 \mathrm{f}-\mathrm{i}$ & 11.66 & def & 7.25 \\
\hline $0.5 \mathrm{ppm} 1-\mathrm{MCP}+0.5 \mathrm{mM} \mathrm{SA}$ & $0.00 \mathrm{~s}$ & 4.47 & $\mathrm{qr}$ & 7.16 & $\operatorname{lmn}$ & $9.13 \mathrm{hij}$ & 10.83 & $\mathrm{fg}$ & 6.32 \\
\hline $0.5 \mathrm{ppm} 1-\mathrm{MCP}+1 \mathrm{mM} \mathrm{SA}$ & $0.00 \mathrm{~s}$ & 4.04 & $\mathrm{r}$ & 6.05 & nop & $7.60 \mathrm{klm}$ & 8.98 & ijk & 5.34 \\
\hline $1 \mathrm{ppm} 1-\mathrm{MCP}+0.5 \mathrm{mM} \mathrm{SA}$ & $0.00 \mathrm{~s}$ & 4.76 & pqr & 7.62 & $\mathrm{klm}$ & 9.24 hij & 11.20 & ef & 6.56 \\
\hline 1 ppm 1-MCP + 1 mM SA & $0.00 \mathrm{~s}$ & 4.69 & pqr & 7.36 & $\operatorname{lmn}$ & 9.15 hij & 10.90 & fg & 6.42 \\
\hline \multirow[t]{2}{*}{ Means } & $0.00 \mathrm{E}$ & 5.96 & $\mathrm{D}$ & 9.02 & $\mathrm{C}$ & $11.17 \mathrm{~B}$ & 13.02 & $\mathrm{~A}$ & \\
\hline & \multicolumn{8}{|c|}{ Season 2016} & \\
\hline Distilled water (control) & $0.00 \mathrm{n}$ & 11.75 & $\mathrm{e}$ & 15.98 & $\mathrm{c}$ & $19.63 \mathrm{~b}$ & 23.92 & $\mathrm{a}$ & $14.25 \mathrm{~A}$ \\
\hline $0.5 \mathrm{ppm} 1-\mathrm{MCP}$ & $0.00 \mathrm{n}$ & 6.56 & $\mathrm{j}$ & 8.57 & $\mathrm{~h}$ & $11.53 \mathrm{e}$ & 13.34 & $\mathrm{~d}$ & $8.00 \mathrm{~B}$ \\
\hline 1 ppm 1-MCP & $0.00 \mathrm{n}$ & 6.21 & $\mathrm{jk}$ & 8.20 & $\mathrm{~h}$ & $11.31 \mathrm{e}$ & 12.87 & $\mathrm{~d}$ & 7.72 \\
\hline $0.5 \mathrm{mM} \mathrm{SA}$ & $0.00 \mathrm{n}$ & 6.51 & $\mathrm{j}$ & 8.28 & $\mathrm{~h}$ & $11.21 \mathrm{e}$ & 13.20 & $\mathrm{~d}$ & 7.84 \\
\hline $1 \mathrm{mM}$ SA & $0.00 \mathrm{n}$ & 6.33 & $\mathrm{jk}$ & 8.18 & $\mathrm{~h}$ & 10.97 ef & 12.81 & $\mathrm{~d}$ & 7.66 \\
\hline $0.5 \mathrm{ppm} 1-\mathrm{MCP}+0.5 \mathrm{mM} \mathrm{SA}$ & $0.00 \mathrm{n}$ & 4.10 & $\mathrm{~m}$ & 6.24 & $\mathrm{jk}$ & $8.50 \mathrm{~h}$ & 9.97 & fg & 5.76 \\
\hline $0.5 \mathrm{ppm} 1-\mathrm{MCP}+1 \mathrm{mM} \mathrm{SA}$ & $0.00 \mathrm{n}$ & 3.67 & $\mathrm{~m}$ & 5.30 & $\mathrm{kl}$ & $7.93 \mathrm{hi}$ & 8.58 & $\mathrm{~h}$ & 5.10 \\
\hline $1 \mathrm{ppm} 1-\mathrm{MCP}+0.5 \mathrm{mM} \mathrm{SA}$ & $0.00 \mathrm{n}$ & 4.59 & $\operatorname{lm}$ & 6.94 & ij & $9.05 \mathrm{gh}$ & 11.12 & e & 6.34 \\
\hline 1 ppm 1-MCP + 1 mM SA & $0.00 \mathrm{n}$ & 4.52 & $\operatorname{lm}$ & 6.53 & $\mathrm{j}$ & $8.78 \mathrm{~h}$ & 10.68 & ef & 6.10 \\
\hline Means & $0.00 \mathrm{E}$ & 6.03 & $\mathrm{D}$ & 8.25 & $\mathrm{C}$ & $10.99 \mathrm{~B}$ & 12.94 & $\mathrm{~A}$ & \\
\hline
\end{tabular}

Means followed by the same letters within pre-storage treatments, storage periods and their interactions in each season are not significantly different at level $P \leq 0.05$ according to DMRT.

The duration of the exposure to 1-MCP and SA dipping were 24 hours and 5 minutes, respectively. 
TABLE 2. Changes in decay percentage of 'Canino' apricots treated with exposure to 1-methylcyclopropene (1MCP) application, salicylic acid (SA) dipping and their combined treatments during cold storage at $0^{\circ} \mathrm{C}$ for 28 days

\begin{tabular}{|c|c|c|c|c|c|c|c|c|c|c|c|}
\hline \multirow{3}{*}{ Pre-storage treatments } & \multicolumn{9}{|c|}{ Storage period (days) } & \multirow{3}{*}{\multicolumn{2}{|c|}{ Means }} \\
\hline & $\mathbf{0}$ & & 7 & & 14 & & 21 & & 28 & & \\
\hline & \multicolumn{9}{|c|}{ Season 2015} & & \\
\hline Distilled water (control) & $0.00 \mathrm{~g}$ & 7.69 & efg & 10.35 & $c-f$ & 25.34 & $\mathrm{~b}$ & 40.15 & $\mathrm{a}$ & 16.71 & A \\
\hline 0.5 ppm 1-MCP & $0.00 \mathrm{~g}$ & 0.00 & $\mathrm{~g}$ & 0.00 & $\mathrm{~g}$ & 10.75 & $c-f$ & 18.72 & $\mathrm{bc}$ & 5.89 & $\mathrm{~B}$ \\
\hline 1 ppm 1-MCP & $0.00 \mathrm{~g}$ & 0.00 & $\mathrm{~g}$ & 0.00 & $\mathrm{~g}$ & 8.99 & d-g & 16.83 & b-e & 5.17 & $\mathrm{~B}$ \\
\hline $0.5 \mathrm{mM}$ SA & $0.00 \mathrm{~g}$ & 0.00 & $\mathrm{~g}$ & 0.00 & $\mathrm{~g}$ & 11.13 & $c-f$ & 20.94 & $\mathrm{~b}$ & 6.42 & B \\
\hline $1 \mathrm{mM} \mathrm{SA}$ & $0.00 \mathrm{~g}$ & 0.00 & $\mathrm{~g}$ & 0.00 & $\mathrm{~g}$ & 10.23 & $c-f$ & 17.07 & bed & 5.46 & B \\
\hline $0.5 \mathrm{ppm} 1-\mathrm{MCP}+0.5 \mathrm{mM}$ SA & $0.00 \mathrm{~g}$ & 0.00 & g & 0.00 & $\mathrm{~g}$ & 0.00 & g & 4.71 & fg & 0.94 & $\mathrm{C}$ \\
\hline 0.5 ppm 1-MCP + 1 mM SA & $0.00 \mathrm{~g}$ & 0.00 & $\mathrm{~g}$ & 0.00 & $\mathrm{~g}$ & 0.00 & $\mathrm{~g}$ & 3.43 & fg & 0.69 & $\mathrm{C}$ \\
\hline $1 \mathrm{ppm} 1-\mathrm{MCP}+0.5 \mathrm{mM}$ SA & $0.00 \mathrm{~g}$ & 0.00 & g & 0.00 & $\mathrm{~g}$ & 0.00 & $\mathrm{~g}$ & 6.21 & fg & 1.24 & $\mathrm{C}$ \\
\hline 1 ppm 1-MCP + 1 mM SA & $0.00 \mathrm{~g}$ & 0.00 & $\mathrm{~g}$ & 0.00 & $\mathrm{~g}$ & 0.00 & $\mathrm{~g}$ & 5.25 & fg & 1.05 & $\mathrm{C}$ \\
\hline \multirow[t]{2}{*}{ Means } & $0.00 \mathrm{C}$ & 0.85 & $\mathrm{C}$ & 1.15 & $\mathrm{C}$ & 7.38 & $\mathrm{~B}$ & 14.81 & $\mathrm{~A}$ & & \\
\hline & \multicolumn{9}{|c|}{ Season 2016} & & \\
\hline Distilled water (control) & $0.00 \mathrm{f}$ & 8.94 & def & 14.58 & cde & 26.98 & $\mathrm{~b}$ & 43.11 & $\mathrm{a}$ & 18.72 & A \\
\hline 0.5 ppm 1-MCP & $0.00 \mathrm{f}$ & 0.00 & $\mathrm{f}$ & 0.00 & $\mathrm{f}$ & 12.23 & cde & 19.48 & bed & 6.34 & B \\
\hline 1 ppm 1-МCP & $0.00 \mathrm{f}$ & 0.00 & $\mathrm{f}$ & 0.00 & $\mathrm{f}$ & 11.26 & de & 18.61 & bed & 5.97 & B \\
\hline $0.5 \mathrm{mM}$ SA & $0.00 \mathrm{f}$ & 0.00 & $\mathrm{f}$ & 0.00 & $\mathrm{f}$ & 14.56 & cde & 22.68 & $\mathrm{bc}$ & 7.45 & $\mathrm{~B}$ \\
\hline $1 \mathrm{mM} \mathrm{SA}$ & $0.00 \mathrm{f}$ & 0.00 & $\mathrm{f}$ & 0.00 & $\mathrm{f}$ & 11.96 & de & 18.75 & bcd & 6.14 & $\mathrm{~B}$ \\
\hline $0.5 \mathrm{ppm} 1-\mathrm{MCP}+0.5 \mathrm{mM}$ SA & $0.00 \mathrm{f}$ & 0.00 & $\mathrm{f}$ & 0.00 & $\mathrm{f}$ & 0.00 & $\mathrm{f}$ & 5.52 & ef & 1.10 & $\mathrm{C}$ \\
\hline 0.5 ppm 1-MCP + 1 mM SA & $0.00 \mathrm{f}$ & 0.00 & $\mathrm{f}$ & 0.00 & $\mathrm{f}$ & 0.00 & $\mathrm{f}$ & 3.83 & ef & 0.77 & $\mathrm{C}$ \\
\hline $1 \mathrm{ppm} 1-\mathrm{MCP}+0.5 \mathrm{mM}$ SA & $0.00 \mathrm{f}$ & 0.00 & $\mathrm{f}$ & 0.00 & $\mathrm{f}$ & 0.00 & $\mathrm{f}$ & 6.76 & ef & 1.35 & $\mathrm{C}$ \\
\hline 1 ppm 1-MCP + 1 mM SA & $0.00 \mathrm{f}$ & 0.00 & $\mathrm{f}$ & 0.00 & $\mathrm{f}$ & 0.00 & $\mathrm{f}$ & 5.63 & ef & 1.13 & $\mathrm{C}$ \\
\hline Means & $0.00 \mathrm{C}$ & 0.99 & $\mathrm{C}$ & 1.62 & $\mathrm{C}$ & 8.55 & $\mathrm{~B}$ & 16.04 & $\mathrm{~A}$ & & \\
\hline
\end{tabular}

Means followed by the same letters within pre-storage treatments, storage periods and their interactions in each season are not significantly different at level $P \leq 0.05$ according to DMRT.

The duration of the exposure to 1-MCP and SA dipping were 24 hours and 5 minutes, respectively.

ABLE 3. Changes in marketable percentage of 'Canino' apricots treated with exposure to 1-methylcyclopropene (1-MCP) application, salicylic acid (SA) dipping and their combined treatments during cold storage at $0^{\circ} \mathrm{C}$ for 28 days

\begin{tabular}{|c|c|c|c|c|c|c|c|c|c|}
\hline \multirow{3}{*}{ Pre-storage treatments } & \multicolumn{8}{|c|}{ Storage period (days) } & \multirow{3}{*}{ Means } \\
\hline & $\mathbf{0}$ & & 7 & 14 & & 21 & & 28 & \\
\hline & \multicolumn{8}{|c|}{ Season 2015} & \\
\hline Distilled water (control) & 100.00 & $\mathrm{a}$ & $81.38 \mathrm{fgh}$ & 75.02 hij & 58.57 & & 44.06 & 1 & $71.81 \mathrm{C}$ \\
\hline 0.5 ppm 1-MCP & 100.00 & $\mathrm{a}$ & $93.60 \mathrm{ab}$ & $90.41 \mathrm{~b}-\mathrm{e}$ & 78.92 & ghi & 70.95 & $\mathrm{j}$ & $86.77 \mathrm{~B}$ \\
\hline 1 ppm 1-МCP & 100.00 & $\mathrm{a}$ & $93.40 \mathrm{abc}$ & 90.37 b-e & 80.70 & $f-i$ & 72.67 & ij & $87.43 \mathrm{~B}$ \\
\hline $0.5 \mathrm{mM}$ SA & 100.00 & $\mathrm{a}$ & $94.76 \mathrm{ab}$ & $91.10 \mathrm{~b}-\mathrm{e}$ & 79.43 & ghi & 69.59 & $\mathrm{j}$ & $86.98 \mathrm{~B}$ \\
\hline $1 \mathrm{mM} \mathrm{SA}$ & 100.00 & $\mathrm{a}$ & $94.40 \mathrm{ab}$ & 91.43 a-e & 80.40 & $\mathrm{f}-\mathrm{i}$ & 73.26 & $\mathrm{ij}$ & $87.90 \mathrm{~B}$ \\
\hline $0.5 \mathrm{ppm} 1-\mathrm{MCP}+0.5 \mathrm{mM} \mathrm{SA}$ & 100.00 & $\mathrm{a}$ & $95.53 \mathrm{ab}$ & $92.84 \mathrm{a}-\mathrm{d}$ & 90.87 & b-e & 85.00 & $\mathrm{c}-\mathrm{g}$ & $92.85 \mathrm{~A}$ \\
\hline 0.5 ppm 1-MCP + 1 mM SA & 100.00 & $\mathrm{a}$ & $95.96 \mathrm{ab}$ & $93.95 \mathrm{ab}$ & 92.40 & $a-d$ & 87.91 & $b-f$ & $94.04 \mathrm{~A}$ \\
\hline $1 \mathrm{ppm} 1-\mathrm{MCP}+0.5 \mathrm{mM} \mathrm{SA}$ & 100.00 & $\mathrm{a}$ & $95.24 \mathrm{ab}$ & $92.38 \mathrm{a}-\mathrm{d}$ & 90.76 & $b-e$ & 83.32 & efg & $92.34 \mathrm{~A}$ \\
\hline 1 ppm 1-MCP + 1 mM SA & 100.00 & $\mathrm{a}$ & $95.31 \mathrm{ab}$ & 92.64 a-d & 90.85 & $b-e$ & 84.40 & d-g & $92.64 \mathrm{~A}$ \\
\hline \multirow[t]{2}{*}{ Means } & 100.00 & A & $93.29 \mathrm{~B}$ & $90.02 \mathrm{C}$ & 82.55 & $\mathrm{D}$ & 74.57 & $\mathrm{E}$ & \\
\hline & \multicolumn{8}{|c|}{ Season 2016} & \\
\hline Distilled water (control) & 100.00 & $\mathrm{a}$ & $80.38 \mathrm{fgh}$ & $71.74 \mathrm{hij}$ & 58.70 & $\mathrm{k}$ & 43.29 & 1 & $70.82 \mathrm{C}$ \\
\hline 0.5 ppm 1-MCP & 100.00 & $\mathrm{a}$ & 93.44 a-d & $91.43 \mathrm{a}-\mathrm{e}$ & 77.66 & ghi & 69.78 & $\mathrm{ij}$ & $86.46 \mathrm{~B}$ \\
\hline 1 ppm 1-MCP & 100.00 & $\mathrm{a}$ & 93.79 a-d & 91.80 a-e & 78.72 & $\mathrm{f}-\mathrm{i}$ & 70.90 & $\mathrm{ij}$ & $87.04 \mathrm{~B}$ \\
\hline $0.5 \mathrm{mM} \mathrm{SA}$ & 100.00 & a & 93.49 a-d & 91.72 a-e & 75.85 & $g-j$ & 67.11 & $\mathrm{j}$ & $85.63 \mathrm{~B}$ \\
\hline 1 mM SA & 100.00 & $\mathrm{a}$ & $93.67 \mathrm{a}-\mathrm{d}$ & 91.82 a-e & 78.39 & ghi & 70.84 & ij & $86.94 \mathrm{~B}$ \\
\hline $0.5 \mathrm{ppm} 1-\mathrm{MCP}+0.5 \mathrm{mM} \mathrm{SA}$ & 100.00 & $\mathrm{a}$ & $95.90 \mathrm{ab}$ & 93.76 a-d & 91.50 & $a-e$ & 85.11 & $\mathrm{c}-\mathrm{g}$ & $93.25 \mathrm{~A}$ \\
\hline 0.5 ppm 1-MCP + 1 mM SA & 100.00 & $\mathrm{a}$ & $96.33 \mathrm{ab}$ & $94.70 \mathrm{abc}$ & 92.07 & $\mathrm{a}-\mathrm{e}$ & 87.93 & $b-f$ & $94.21 \mathrm{~A}$ \\
\hline $1 \mathrm{ppm} 1-\mathrm{MCP}+0.5 \mathrm{mM}$ SA & 100.00 & $\mathrm{a}$ & $95.41 \mathrm{ab}$ & $93.06 \mathrm{a}-\mathrm{d}$ & 90.95 & $a-e$ & 82.93 & efg & $92.47 \mathrm{~A}$ \\
\hline 1 ppm 1-MCP + 1 mM SA & 100.00 & $\mathrm{a}$ & $95.48 \mathrm{ab}$ & 93.47 a-d & 91.22 & $a-e$ & 84.31 & d-g & $92.90 \mathrm{~A}$ \\
\hline Means & 100.00 & A & $93.10 \mathrm{~B}$ & $90.39 \mathrm{~B}$ & 81.67 & $\mathrm{C}$ & 73.58 & $\mathrm{D}$ & \\
\hline
\end{tabular}

Means followed by the same letters within pre-storage treatments, storage periods and their interactions in each season are not significantly different at level $P \leq 0.05$ according to DMRT.

The duration of the exposure to 1-MCP and SA dipping were 24 hours and 5 minutes, respectively.

Egypt. J. Hort. Vol. 45, No.1 (2018) 
TABLE 4. Changes in firmness (N) of 'Canino' apricots treated with exposure to 1-methylcyclopropene (1-MCP) application, salicylic acid (SA) dipping and their combined treatments during cold storage at $0^{\circ} \mathrm{C}$ for 28 days

\begin{tabular}{|c|c|c|c|c|c|c|c|c|}
\hline \multirow{3}{*}{ Pre-storage treatments } & \multicolumn{7}{|c|}{ Storage period (days) } & \multirow{3}{*}{ Means } \\
\hline & & $\mathbf{0}$ & 7 & 14 & & 21 & 28 & \\
\hline & \multicolumn{7}{|c|}{ Season 2015} & \\
\hline Distilled water (control) & 24.53 & $\mathrm{a}$ & $17.99 \mathrm{k}$ & $11.77 \mathrm{~m}$ & 7.85 & $\mathrm{~N}$ & $4.25 \quad 0$ & $13.28 \mathrm{E}$ \\
\hline 1 ppm 1-MCP & 24.53 & $\mathrm{a}$ & $22.24 \mathrm{a}-\mathrm{f}$ & $20.60 \mathrm{e}-\mathrm{j}$ & 19.29 & $\mathrm{~h}-\mathrm{k}$ & 15.701 & $20.47 \mathrm{C}$ \\
\hline $0.5 \mathrm{mM} \mathrm{SA}$ & 24.53 & $\mathrm{a}$ & $20.60 \mathrm{e}-\mathrm{j}$ & $19.29 \mathrm{~h}-\mathrm{k}$ & 17.99 & $\mathrm{~K}$ & 14.721 & $19.42 \mathrm{D}$ \\
\hline $1 \mathrm{mM} S \mathrm{SA}$ & 24.53 & $\mathrm{a}$ & $21.91 \mathrm{~b}-\mathrm{g}$ & $20.27 \mathrm{f}-\mathrm{k}$ & 18.97 & $\mathrm{Ijk}$ & 15.371 & $20.21 \mathrm{CD}$ \\
\hline 0.5 ppm 1-MCP + 1 mM SA & 24.53 & $\mathrm{a}$ & $23.87 \mathrm{ab}$ & 23.22 a-d & 21.91 & $\mathrm{~b}-\mathrm{g}$ & $19.95 \mathrm{f}-\mathrm{k}$ & $22.69 \mathrm{~A}$ \\
\hline $1 \mathrm{ppm} 1-\mathrm{MCP}+0.5 \mathrm{mM} \mathrm{SA}$ & 24.53 & $\mathrm{a}$ & 22.89 a-e & $21.91 \mathrm{~b}-\mathrm{g}$ & 20.27 & $\mathrm{f}-\mathrm{k}$ & $17.99 \mathrm{k}$ & $21.52 \mathrm{~B}$ \\
\hline 1 ppm 1-MCP + 1 mM SA & 24.53 & $\mathrm{a}$ & $23.22 \mathrm{a}-\mathrm{d}$ & $22.24 \mathrm{a}-\mathrm{f}$ & 20.93 & $\mathrm{~d}-\mathrm{i}$ & $18.31 \mathrm{jk}$ & $21.84 \mathrm{AB}$ \\
\hline \multirow[t]{2}{*}{ Means } & 24.53 & A & $21.98 \mathrm{~B}$ & $20.13 \mathrm{C}$ & 18.53 & $\mathrm{D}$ & $15.59 \mathrm{E}$ & \\
\hline & \multicolumn{7}{|c|}{ Season 2016} & \\
\hline Distilled water (control) & 23.87 & $\mathrm{a}$ & $17.66 \mathrm{j}-\mathrm{n}$ & $11.12 \mathrm{q}$ & 7.19 & $\mathrm{R}$ & $3.92 \mathrm{~s}$ & $12.75 \mathrm{D}$ \\
\hline $0.5 \mathrm{ppm} 1-\mathrm{MCP}+0.5 \mathrm{mM} \mathrm{SA}$ & 23.87 & $\mathrm{a}$ & 22.56 abc & $20.60 \mathrm{c}-\mathrm{h}$ & 19.62 & $e-j$ & $18.31 \mathrm{i}-\mathrm{n}$ & $20.99 \mathrm{AB}$ \\
\hline 0.5 ppm 1-MCP + 1 mM SA & 23.87 & $\mathrm{a}$ & $23.22 \mathrm{ab}$ & $21.58 \mathrm{~b}-\mathrm{e}$ & 20.60 & $\mathrm{c}-\mathrm{h}$ & $19.29 \mathrm{f}-\mathrm{k}$ & $21.71 \mathrm{~A}$ \\
\hline $1 \mathrm{ppm} 1-\mathrm{MCP}+0.5 \mathrm{mM} \mathrm{SA}$ & 23.87 & $\mathrm{a}$ & 21.91 a-d & $20.27 \mathrm{~d}-\mathrm{i}$ & 18.64 & $\mathrm{~h}-\mathrm{m}$ & $17.33 \mathrm{k}-\mathrm{n}$ & $20.40 \mathrm{~B}$ \\
\hline 1 ppm 1-MCP + 1 mM SA & 23.87 & $\mathrm{a}$ & 22.24 a-d & $20.60 \mathrm{c}-\mathrm{h}$ & 19.29 & $\mathrm{f}-\mathrm{k}$ & $17.66 \mathrm{j}-\mathrm{n}$ & $20.73 \mathrm{~B}$ \\
\hline Means & 23.87 & $\mathrm{~A}$ & $21.33 \mathrm{~B}$ & $18.82 \mathrm{C}$ & 17.00 & $\mathrm{D}$ & $14.82 \mathrm{E}$ & \\
\hline
\end{tabular}

Means followed by the same letters within pre-storage treatments, storage periods and their interactions in each season are not significantly different at level $P \leq 0.05$ according to DMRT.

The duration of the exposure to 1-MCP and SA dipping were 24 hours and 5 minutes, respectively.

Canino apricot fruits treated with the combination of exposure to $0.5 \mathrm{ppm}$ of $1-\mathrm{MCP}$ and $1 \mathrm{mM}$ SA dipping had the lowest weight loss (5.34 $\& 5.10 \%)$ and decay percentage $(0.69 \& 0.77 \%)$ as compared to the other treatments in the first and second seasons, respectively. Moreover, these fruits had the highest marketable fruit percentage (94.04 \& $94.21 \%)$ and flesh firmness (22.69 \& $21.71 \mathrm{~N})$ in 2015 and 2016 seasons, respectively as compared to all the other treatments. On the other hand, untreated fruits (control) had the highest weight loss (15.22 \& $14.25 \%$ ) and decay incidence $(16.71 \& 18.72 \%)$ as well as had the lowest marketable fruit percentage $(71.81 \& 70.82$ $\%)$ and flesh firmness (13.28 \& $12.75 \mathrm{~N})$ in the first and second seasons, respectively.

With respect to the effect of storage period, data in Tables 1, 2, 3 and 4 demonstrate that, weight loss and decay percentage of 'Canino' apricot fruits generally significantly increased with prolonging of storage period in both seasons. In contrary, 'Canino' apricot fruits showed gradual and significant reduction in marketable percentage and flesh firmness with the advancement of storage

TABLE 5. Changes in fruit physical attributes of 'Canino' apricots treated with exposure to 1-methylcyclopropene (1-MCP) application, salicylic acid (SA) dipping and their combined treatments after cold storage at $0^{\circ} \mathrm{C}$ for 28 days and then transferred to about $25^{\circ} \mathrm{C}$ for 3 days shelf life

\begin{tabular}{|c|c|c|c|c|c|c|c|c|c|}
\hline \multirow[b]{2}{*}{ Pre-storage treatments } & \multicolumn{2}{|c|}{ Weight loss (\%) } & \multicolumn{3}{|c|}{ Decay (\%) } & \multicolumn{2}{|c|}{ Marketable (\%) } & \multicolumn{2}{|c|}{ Firmness (N) } \\
\hline & $\begin{array}{c}\text { Season } \\
2015\end{array}$ & $\begin{array}{c}\text { Season } \\
2016\end{array}$ & $\begin{array}{c}\text { Season } \\
2015\end{array}$ & $\begin{array}{c}\text { Season } \\
2016\end{array}$ & & $\begin{array}{c}\text { Season } \\
2015\end{array}$ & $\begin{array}{c}\text { Season } \\
2016\end{array}$ & $\begin{array}{c}\text { Season } \\
2015\end{array}$ & $\begin{array}{c}\text { Season } \\
2016\end{array}$ \\
\hline Distilled water (control) & $30.95 \mathrm{a}$ & $28.78 \mathrm{a}$ & $67.40 \mathrm{a}$ & $66.05 \mathrm{a}$ & $\mathrm{a}$ & $22.53 \mathrm{c}$ & $24.22 \mathrm{~d}$ & $2.62 \mathrm{f}$ & $2.29 \mathrm{~d}$ \\
\hline 0.5 ppm 1-MCP & $14.43 \mathrm{~b}$ & $14.50 \mathrm{~b}$ & $27.67 \mathrm{~b}$ & 28.83 & $\mathrm{~b}$ & $61.79 \mathrm{~b}$ & $60.85 \mathrm{c}$ & $12.43 \mathrm{de}$ & $12.10 \mathrm{c}$ \\
\hline 1 ppm 1-MCP & $14.32 \mathrm{~b}$ & $14.35 \mathrm{~b}$ & $25.27 \mathrm{~b}$ & $26.17 \mathrm{~b}$ & b & $64.00 \mathrm{~b}$ & $63.22 \mathrm{c}$ & $13.41 \mathrm{~d}$ & $12.75 \mathrm{c}$ \\
\hline $0.5 \mathrm{mM}$ SA & $13.99 \mathrm{~b}$ & $14.44 \mathrm{~b}$ & $29.41 \mathrm{~b}$ & $29.25 \mathrm{~b}$ & $b$ & $60.70 \mathrm{~b}$ & $60.53 \mathrm{c}$ & $11.77 \mathrm{e}$ & $11.77 \mathrm{c}$ \\
\hline 1 mM SA & $13.49 \mathrm{bc}$ & $14.02 \mathrm{~b}$ & $25.98 \mathrm{~b}$ & 27.04 & b & $64.04 \mathrm{~b}$ & $62.73 \mathrm{c}$ & $12.75 \mathrm{de}$ & $12.43 \mathrm{c}$ \\
\hline $0.5 \mathrm{ppm} 1-\mathrm{MCP}+0.5 \mathrm{mM} \mathrm{SA}$ & $12.36 \mathrm{bc}$ & $12.18 \mathrm{c}$ & $10.54 \mathrm{c}$ & 11.87 & $\mathrm{c}$ & $78.33 \mathrm{a}$ & $77.42 \mathrm{ab}$ & $17.00 \mathrm{~b}$ & $16.35 \mathrm{ab}$ \\
\hline 0.5 ppm 1-MCP + 1 mM SA & $10.84 \mathrm{c}$ & $10.95 \mathrm{~d}$ & $7.58 \quad \mathrm{c}$ & 7.38 & $\mathrm{c}$ & $82.39 \mathrm{a}$ & $82.50 \mathrm{a}$ & $18.31 \mathrm{a}$ & $17.99 \mathrm{a}$ \\
\hline $1 \mathrm{ppm} 1-\mathrm{MCP}+0.5 \mathrm{mM} \mathrm{SA}$ & $12.79 \mathrm{bc}$ & $12.89 \mathrm{c}$ & $12.43 \mathrm{c}$ & 12.82 & $\mathrm{c}$ & $76.36 \mathrm{a}$ & $75.93 \mathrm{~b}$ & $15.37 \mathrm{c}$ & $15.04 \mathrm{~b}$ \\
\hline $1 \mathrm{ppm} 1-\mathrm{MCP}+1 \mathrm{mM} \mathrm{SA}$ & $12.78 \mathrm{bc}$ & $12.55 \mathrm{c}$ & $11.98 \mathrm{c}$ & $12.03 \mathrm{c}$ & $\mathrm{c}$ & $76.65 \mathrm{a}$ & $76.93 \mathrm{~b}$ & $16.02 \mathrm{bc}$ & $15.37 \mathrm{~b}$ \\
\hline
\end{tabular}

Means followed by the same letters in each column for every season are not significantly different according to DMRT at level $P \leq 0.05$. The duration of the exposure to 1-MCP and SA dipping were 24 hours and 5 minutes, respectively. 
period in both seasons. The results indicated that, maximum weight loss (13.02 \& $12.94 \%)$, decay percentage (14.81 \& $16.04 \%$ ) and the minimum marketable fruits percentage $(74.57 \& 73.58$ $\%)$ and flesh firmness (15.92 \& $14.82 \mathrm{~N})$ were observed at the end of cold storage period at $0^{\circ} \mathrm{C}$ in the first and second seasons, respectively.

The interaction effect between pre-storage treatments and storage periods were showed significant differences at $p \leq 0.05$ for weight loss, decay and marketable percentages and firmness of 'Canino' apricots in both seasons under this experiment.

The overall results in Table 5 reveal that, all prestorage treatments especially combined treatments showed significantly retarded the deterioration in physical attributes as compared to untreated fruits (control) at the end of cold storage (28 days) plus 3 days shelf life at ambient temperature. Data also showed that, pre-storage treatment of 'Canino' apricots with $0.5 \mathrm{ppm}$ of $1-\mathrm{MCP}$ and 1 $\mathrm{mM}$ of SA had the lowest weight loss and decay percentage and the highest marketable percentage and firmness in the two seasons.

The loss in fruit weight during storage could be attributed to the loss in moisture that occurs through physiological processes such as transpiration and respiration (Srivastava and Dwivedi, 2000 and Wang et al., 2006). The reducing decay appearance may be associated with changes in natural antifungal compounds (Prusky and Keen, 1993) and increase in activities of antioxidant enzyme (Tareen et al., 2012b; Shi et al., 2013 and Ezzat, 2014). 1-MCP and SA are highly effective anti browning agent for fruits (Tareen et al., 2012b and Ezzat, 2014) and enhancement the disease resistance in apricots (Dong et al., 2002 and Valero et al., 2005).

The rate of fruit firmness losses affects on fruit quality and the storage life. Fruit softening starts with the conversion of insoluble protopectin into water soluble pectin and associated with dissolution of the middle lamellae that lead to an increase of pectin solubility and depolymerization of matrix polysaccharides (Vicente et al., 2007). The increasing of hydrolytic enzymes activity such as PME, polygalacturonase and betagalactosidase are contributors in reduced rigidity of cell walls and lead to fruit softening (Payasi et al., 2009). Thus, the reduction in flesh firmness of apricots during storage might be due to degradation in cellular structures because of respiration and other metabolic activities (Femenia et al., 1998).

Egypt. J. Hort. Vol. 45, No.1 (2018)
Minimum flesh firmness may be attributing to maximum change in pectin substance as reported for control fruits in this research as documented by Srivastava and Dwivedi (2000), Ahmad et al. (2013), Ezzat (2014) and Özkaya et al. (2016).

The results in the current study suggested that, treated 'Canino' apricot with exposure to either 0.5 or $1 \mathrm{ppm}$ of 1-MCP, dipping apricots in either 0.5 or $1 \mathrm{mM}$ of SA and especially their combined treatments probably reduced respiration, transpiration, maintaining cellular integrity and delaying the activities of cell wall degrading enzymes (Ezzat 2014 and Özkaya et al., 2016). Therefore, treated apricot fruits with exposure to 1-MCP and SA dipping especially their combined treatments reduced weight loss and decay percentages with a significant increase in marketable fruit percentage as well as maintained fruit firmness, thus delayed ripening and senescence processes of apricots.

Our findings in the present study are in agreement with the previous studies by Erkan and Eski (2012) on 'Black Beauty' and 'Autumn Giant' plums, Shi et al. (2013) on apricots and Mohamed et al. (2016b) on 'Zibda' mangoes. They reported that, 1-MCP treatment reduced fruit weigh loss and decay percentages, increased marketable fruits percentage and maintained fruit firmness during cold storage period and shelf life. Also, the obtained results are in harmony with reports that $1-\mathrm{MCP}$ application delayed fruit softening in a number of crops including, apricots and plums (Dong et al., 2002 and Fan et al., 2000), peaches (Jin et al., 2011) and nectarines (Özkaya et al., 2016). Furthermore, the current investigation findings agree with those mentioned by Ali et al., (2013), Hajilou and Fakhimrezaei (2013), Ezzat (2014) and Moradinezhad and Jahani (2016) on apricots. Moreover, these results in accordance with those reported by Wang et al. (2006) and Tareen et al. (2012a, b) on peaches and Mohamed et al. (2016a) on 'Valencia' oranges. They reported that, SA treatment reduced weight loss percentage, decay incidence, increased marketable fruit percentage and maintained fruit firmness as compared with control during cold storage.

Fruit contents in ascorbic acid (AsA), total soluble solids (TSS), titratable acidity (TA) and TSS/TA ratio

Data in Tables 6, 7, 8 and 9 clearly indicate that, pre-storage exposure of 'Canino' apricot fruits to 0.5 or $1 \mathrm{ppm}$ of $1-\mathrm{MCP}$ and SA dipping at 0.5 or $1 \mathrm{mM}$ concentration alone or in combinations 
significantly decreased the deterioration of AsA and TA contents. Moreover, data cleared that, these treatments significantly slowed the increases of fruits contents in TSS and TSS/TA ratio as compared with untreated fruits (control) during the two seasons. However, non-significant differences were observed among co-applications of apricots contents in TA and TSS/TA ratio in the two seasons under this study. In addition, untreated fruits (control) showed an increase in TSS content up to 21 days of cold storage at $0^{\circ} \mathrm{C}$ followed by a decrease as compared to all treated fruits. Also, these results revealed that, 'Canino' apricots exposed to $0.5 \mathrm{ppm}$ 1-MCP then dipped in SA at $1 \mathrm{mM}$ showed the highest contents of AsA (14.91 \& $14.69 \mathrm{mg} / 100 \mathrm{ml}$ juice) and TA (1.48 \& 1.43 $\mathrm{g}$ malic acid/100 $\mathrm{ml}$ juice) with the lowest TSS $\left(12.44 \& 12.61{ }^{\circ}\right.$ Brix) and TSS/TA ratio (8.60 \& 8.94 ) in the first and second seasons, respectively. On contrary, untreated fruits (control) recorded the lowest fruit contents of AsA (12.30 \& 12.25 $\mathrm{mg} / 100 \mathrm{ml}$ juice $)$ and TA $(1.12 \& 1.07 \mathrm{~g}$ malic $\mathrm{acid} / 100 \mathrm{ml}$ juice) as well as recorded the highest fruit contents of TSS (13.35\& $13.51^{\circ}$ Brix) and TSS/TA ratio (13.39 \& 14.18) in 2015 and 2016 seasons, respectively.
Regarding the effect of storage period, our results declared that, AsA and TA contents of 'Canino' apricots continuously and significantly declined with the progress of cold storage periods in both seasons (Tables 6 and 8). On the opposite, TSS fruit contents and TSS/TA ratio significantly increased with prolonging of storage period in both seasons (Tables 7 and 9). Our results in this study revealed that, minimum apricot contents of AsA (12.31 \& $12.14 \mathrm{mg} / 100 \mathrm{ml}$ juice) and TA (1.11 \& $1.12 \mathrm{~g}$ malic acid/100 ml juice) in the first and second seasons, respectively were observed at the end of storage period at $0^{\circ} \mathrm{C}$. On contrast, the highest content of TSS (14.16 \& $14.29^{\circ}$ Brix) and TSS/TA ratio $(16.25 \& 17.75)$ in the first and second seasons, respectively were recorded at the end of cold storage period at $0^{\circ} \mathrm{C}$.

The interaction effect between pre-storage treatments and storage periods were showed significant differences at $p \leq 0.05$ for AsA, TSS, TA and TSS/TA ratio of 'Canino' apricot fruits in both seasons in this work.

Statistical data tabulated in Table 10 demonstrate that, all pre-storage treatments especially combined treatments had the highest

TABLE 6. Changes in ascorbic acid content ( $\mathrm{mg} / 100 \mathrm{ml}$ juice) of 'Canino' apricots treated with exposure to 1-methylcyclopropene (1-MCP) application, salicylic acid (SA) dipping and their combined treatments during cold storage at $0^{\circ} \mathrm{C}$ for 28 days

\begin{tabular}{|c|c|c|c|c|c|c|c|}
\hline \multirow{3}{*}{ Pre-storage treatments } & \multicolumn{6}{|c|}{ Storage period (days) } & \multirow{3}{*}{ Means } \\
\hline & 0 & 7 & 14 & & 21 & 28 & \\
\hline & \multicolumn{6}{|c|}{ Season 2015} & \\
\hline Distilled water (control) & $15.94 \mathrm{a}$ & $13.04 \mathrm{~h}-\mathrm{n}$ & $11.94 \mathrm{mno}$ & 10.84 & op & $9.72 \mathrm{p}$ & $12.30 \mathrm{G}$ \\
\hline 0.5 ppm 1-MCP & $15.94 \mathrm{a}$ & $14.20 \mathrm{c}-\mathrm{j}$ & $13.06 \mathrm{~h}-\mathrm{n}$ & 12.74 & $j-n$ & 11.94 mno & $13.58 \mathrm{EF}$ \\
\hline 1 ppm 1-MCP & $15.94 \mathrm{a}$ & $14.78 \mathrm{a}-\mathrm{f}$ & $13.61 \mathrm{e}-1$ & 13.28 & $\mathrm{~g}-\mathrm{m}$ & $12.50 \mathrm{k}-\mathrm{n}$ & $14.02 \mathrm{CDE}$ \\
\hline $0.5 \mathrm{mM} \mathrm{SA}$ & $15.94 \mathrm{a}$ & $13.91 \mathrm{~d}-\mathrm{k}$ & $12.78 \mathrm{j}-\mathrm{n}$ & 12.47 & $\mathrm{k}-\mathrm{n}$ & 11.67 no & $13.35 \mathrm{~F}$ \\
\hline $1 \mathrm{mM} \mathrm{SA}$ & $15.94 \mathrm{a}$ & $14.49 \mathrm{a}-\mathrm{h}$ & $13.33 \mathrm{f}-\mathrm{m}$ & 13.01 & $i-n$ & $12.22 \operatorname{lmn}$ & 13.80 DEF \\
\hline $0.5 \mathrm{ppm} 1-\mathrm{MCP}+0.5 \mathrm{mM} \mathrm{SA}$ & $15.94 \mathrm{a}$ & $15.36 \mathrm{abc}$ & $14.72 \mathrm{a}-\mathrm{g}$ & 14.09 & $c-j$ & $13.33 \mathrm{f}-\mathrm{m}$ & $14.69 \mathrm{AB}$ \\
\hline 0.5 ppm 1-MCP + 1 mM SA & $15.94 \mathrm{a}$ & $15.65 \mathrm{ab}$ & 15.00 a-e & 14.36 & $b-i$ & $13.61 \mathrm{e}-1$ & $14.91 \mathrm{~A}$ \\
\hline $1 \mathrm{ppm} 1-\mathrm{MCP}+0.5 \mathrm{mM} \mathrm{SA}$ & $15.94 \mathrm{a}$ & $14.78 \mathrm{a}-\mathrm{f}$ & $14.17 \mathrm{c}-\mathrm{j}$ & 13.55 & $\mathrm{f}-1$ & $12.78 \mathrm{j}-\mathrm{n}$ & $14.24 \mathrm{BCD}$ \\
\hline 1 ppm 1-MCP + 1 mM SA & $15.94 \mathrm{a}$ & $15.07 \mathrm{a}-\mathrm{d}$ & $14.44 \mathrm{~b}-\mathrm{i}$ & 13.82 & $\mathrm{~d}-\mathrm{k}$ & $13.06 \mathrm{~h}-\mathrm{n}$ & 14.47 $\mathrm{ABC}$ \\
\hline \multirow[t]{2}{*}{ Means } & $15.94 \mathrm{~A}$ & $14.59 \mathrm{~B}$ & $13.67 \mathrm{C}$ & 13.13 & $\mathrm{D}$ & $12.31 \mathrm{E}$ & \\
\hline & \multicolumn{6}{|c|}{ Season 2016} & \\
\hline Distilled water (control) & $15.69 \mathrm{a}$ & $12.95 \mathrm{~g}-1$ & $11.92 \operatorname{lmn}$ & 10.85 & $\mathrm{o}$ & $9.84 \mathrm{p}$ & $12.25 \mathrm{~F}$ \\
\hline $0.5 \mathrm{ppm} 1-\mathrm{MCP}$ & $15.69 \mathrm{a}$ & $13.77 \mathrm{~d}-\mathrm{h}$ & $13.01 \mathrm{~g}-1$ & 12.43 & $i-n$ & $11.75 \mathrm{mno}$ & $13.33 \mathrm{DE}$ \\
\hline 1 ppm 1-MCP & $15.69 \mathrm{a}$ & $14.33 \mathrm{~b}-\mathrm{f}$ & $13.55 \mathrm{e}-\mathrm{i}$ & 12.96 & g-1 & $12.30 \mathrm{j}-\mathrm{n}$ & $13.76 \mathrm{CD}$ \\
\hline $0.5 \mathrm{mM} \mathrm{SA}$ & $15.69 \mathrm{a}$ & $13.22 \mathrm{f}-\mathrm{j}$ & $12.74 \mathrm{~h}-\mathrm{m}$ & 12.43 & i-n & 11.48 no & $13.11 \mathrm{E}$ \\
\hline $1 \mathrm{mM} \mathrm{SA}$ & $15.69 \mathrm{a}$ & $14.05 \mathrm{c}-\mathrm{g}$ & $13.28 \mathrm{f}-\mathrm{j}$ & 12.70 & $\mathrm{~h}-\mathrm{m}$ & $12.02 \mathrm{k}-\mathrm{n}$ & $13.55 \mathrm{DE}$ \\
\hline $0.5 \mathrm{ppm} 1-\mathrm{MCP}+0.5 \mathrm{mM} \mathrm{SA}$ & $15.69 \mathrm{a}$ & $15.15 \mathrm{abc}$ & $14.63 \mathrm{a}-\mathrm{e}$ & 13.76 & $\mathrm{~d}-\mathrm{h}$ & $13.11 \mathrm{~g}-\mathrm{k}$ & $14.47 \mathrm{AB}$ \\
\hline 0.5 ppm 1-MCP + 1 mM SA & $15.69 \mathrm{a}$ & $15.43 \mathrm{ab}$ & $14.91 \mathrm{a}-\mathrm{d}$ & 14.02 & $c-g$ & $13.39 \mathrm{f}-\mathrm{j}$ & $14.69 \mathrm{~A}$ \\
\hline $1 \mathrm{ppm} 1-\mathrm{MCP}+0.5 \mathrm{mM} \mathrm{SA}$ & $15.69 \mathrm{a}$ & $14.60 \mathrm{a}-\mathrm{e}$ & $14.09 \mathrm{c}-\mathrm{g}$ & 13.23 & $f-j$ & $12.57 \mathrm{i}-\mathrm{n}$ & $14.03 \mathrm{BC}$ \\
\hline 1 ppm 1-MCP + 1 mM SA & $15.69 \mathrm{a}$ & $14.88 \mathrm{a}-\mathrm{d}$ & $14.36 \mathrm{~b}-\mathrm{f}$ & 13.49 & $e-i$ & 12.84 h-m & $14.25 \mathrm{AB}$ \\
\hline Means & $15.69 \mathrm{~A}$ & $14.26 \mathrm{~B}$ & $13.61 \mathrm{C}$ & 12.87 & $\mathrm{D}$ & $12.14 \mathrm{E}$ & \\
\hline
\end{tabular}

Means followed by the same letters within pre-storage treatments, storage periods and their interactions in each season are not significantly different at level $P \leq 0.05$ according to DMRT.

The duration of the exposure to 1-MCP and SA dipping were 24 hours and 5 minutes, respectively. 
TABLE 7. Changes in total soluble solids content $\left({ }^{\circ} \mathrm{Brix}\right)$ of 'Canino' apricots treated with exposure to 1-methylcyclopropene (1-MCP) application, salicylic acid (SA) dipping and their combined treatments during cold storage at $0^{\circ} \mathrm{C}$ for 28 days

\begin{tabular}{|c|c|c|c|c|c|c|c|c|c|}
\hline \multirow{3}{*}{ Pre-storage treatments } & \multicolumn{8}{|c|}{ Storage period (days) } & \multirow{3}{*}{ Means } \\
\hline & $\mathbf{0}$ & & & 7 & 14 & 21 & & 28 & \\
\hline & \multicolumn{8}{|c|}{ Season 2015} & \\
\hline Distilled water (control) & 11.27 & $\mathrm{r}$ & 12.40 & $\mathrm{k}-\mathrm{o}$ & $13.93 \mathrm{c}-\mathrm{h}$ & $14.73 \mathrm{a}$ & 14.40 & $a b$ & $13.35 \mathrm{~A}$ \\
\hline 0.5 ppm 1-MCP & 11.27 & $\mathrm{r}$ & 12.13 & $m-p$ & $12.60 \mathrm{kl}$ & $13.80 \mathrm{~d}-\mathrm{i}$ & 14.27 & bc & $12.81 \mathrm{BC}$ \\
\hline 1 ppm 1-MCP & 11.27 & $\mathrm{r}$ & 12.00 & op & $12.40 \mathrm{k}-\mathrm{o}$ & $13.67 \mathrm{f}-\mathrm{j}$ & 14.20 & bcd & $12.71 \mathrm{CDE}$ \\
\hline $0.5 \mathrm{mM} \mathrm{SA}$ & 11.27 & $\mathrm{r}$ & 12.20 & $1-p$ & $12.67 \mathrm{k}$ & $13.93 \mathrm{c}-\mathrm{h}$ & 14.33 & bc & $12.88 \mathrm{~B}$ \\
\hline 1 mM SA & 11.27 & $\mathrm{r}$ & 12.07 & nop & $12.53 \mathrm{klm}$ & $13.73 \mathrm{e}-\mathrm{i}$ & 14.20 & bcd & $12.76 \mathrm{BCD}$ \\
\hline $0.5 \mathrm{ppm} 1-\mathrm{MCP}+0.5 \mathrm{mM} \mathrm{SA}$ & 11.27 & $\mathrm{r}$ & 11.80 & $\mathrm{pq}$ & $12.33 \mathrm{k}-\mathrm{o}$ & $13.47 \mathrm{ij}$ & 14.00 & $b-g$ & $12.57 \mathrm{EF}$ \\
\hline 0.5 ppm 1-MCP + 1 mM SA & 11.27 & $\mathrm{r}$ & 11.60 & $\mathrm{gr}$ & $12.201-p$ & $13.33 \mathrm{j}$ & 13.80 & $\mathrm{~d}-\mathrm{i}$ & $12.44 \mathrm{~F}$ \\
\hline $1 \mathrm{ppm} 1-\mathrm{MCP}+0.5 \mathrm{mM} \mathrm{SA}$ & 11.27 & $\mathrm{r}$ & 11.93 & $\mathrm{pq}$ & $12.40 \mathrm{k}-\mathrm{o}$ & $13.60 \mathrm{~g}-\mathrm{j}$ & 14.13 & b-e & $12.67 \mathrm{CDE}$ \\
\hline 1 ppm 1-MCP + 1 mM SA & 11.27 & $\mathrm{r}$ & 11.87 & $\mathrm{pq}$ & $12.47 \mathrm{k}-\mathrm{n}$ & $13.53 \mathrm{hij}$ & 14.07 & $b-f$ & $12.64 \mathrm{DE}$ \\
\hline \multirow[t]{2}{*}{ Means } & 11.27 & $\mathrm{E}$ & 12.00 & $\mathrm{D}$ & $12.61 \mathrm{C}$ & $13.76 \mathrm{~B}^{\circ}$ & 14.16 & $\mathrm{~A}$ & \\
\hline & \multicolumn{8}{|c|}{ Season 2016} & \\
\hline Distilled water (control) & 11.40 & $\mathrm{q}$ & 12.73 & $\mathrm{jkl}$ & 14.00 def & $14.93 \mathrm{a}$ & 14.47 & $\mathrm{~b}$ & $13.51 \mathrm{~A}$ \\
\hline 0.5 ppm 1-MCP & 11.40 & $\mathrm{q}$ & 12.40 & $\operatorname{lmn}$ & $12.87 \mathrm{j}$ & $13.87 \mathrm{~d}-\mathrm{g}$ & 14.53 & $\mathrm{~b}$ & $13.01 \mathrm{BC}$ \\
\hline 1 ppm 1-MCP & 11.40 & $\mathrm{q}$ & 12.27 & no & $12.67 \mathrm{j}-\mathrm{m}$ & $13.73 \mathrm{e}-\mathrm{h}$ & 14.40 & $\mathrm{bc}$ & $12.89 \mathrm{CD}$ \\
\hline $0.5 \mathrm{mM}$ SA & 11.40 & $\mathrm{q}$ & 12.47 & $\mathrm{k}-\mathrm{n}$ & $12.93 \mathrm{j}$ & $14.00 \mathrm{def}$ & 14.60 & $\mathrm{~b}$ & $13.08 \mathrm{~B}$ \\
\hline $1 \mathrm{mM} \mathrm{SA}$ & 11.40 & $\mathrm{q}$ & 12.33 & mno & $12.80 \mathrm{jk}$ & $13.80 \mathrm{~d}-\mathrm{h}$ & 14.47 & $\mathrm{~b}$ & $12.96 \mathrm{BC}$ \\
\hline $0.5 \mathrm{ppm} 1-\mathrm{MCP}+0.5 \mathrm{mM} \mathrm{SA}$ & 11.40 & $\mathrm{q}$ & 12.07 & op & $12.60 \mathrm{j}-\mathrm{m}$ & $13.53 \mathrm{hi}$ & 14.00 & def & $12.72 \mathrm{EF}$ \\
\hline $0.5 \mathrm{ppm} 1-\mathrm{MCP}+1 \mathrm{mM} \mathrm{SA}$ & 11.40 & $\mathrm{q}$ & 11.87 & $\mathrm{p}$ & $12.47 \mathrm{k}-\mathrm{n}$ & $13.40 \mathrm{i}$ & 13.93 & def & $12.61 \mathrm{~F}$ \\
\hline $1 \mathrm{ppm} 1-\mathrm{MCP}+0.5 \mathrm{mM} \mathrm{SA}$ & 11.40 & $\mathrm{q}$ & 12.20 & no & $12.67 \mathrm{j}-\mathrm{m}$ & $13.67 \mathrm{f}-\mathrm{i}$ & 14.13 & $\mathrm{~cd}$ & $12.81 \mathrm{DE}$ \\
\hline 1 ppm 1-MCP + 1 mM SA & 11.40 & $\mathrm{q}$ & 12.13 & nop & $12.73 \mathrm{jkl}$ & $13.60 \mathrm{ghi}$ & 14.07 & de & $12.79 \mathrm{DE}$ \\
\hline Means & 11.40 & $\mathrm{E}$ & 12.27 & $\mathrm{D}$ & $12.86 \mathrm{C}$ & $13.84 \mathrm{~B}$ & 14.29 & A & \\
\hline
\end{tabular}

Means followed by the same letters within pre-storage treatments, storage periods and their interactions in each season are not significantly different at level $P \leq 0.05$ according to DMRT.

The duration of the exposure to 1-MCP and SA dipping were 24 hours and 5 minutes, respectively.

TABLE 8. Changes in titratable acidity content ( $\mathrm{g}$ malic acid/100 $\mathrm{ml}$ juice) of 'Canino' apricots treated with exposure to 1-methylcyclopropene (1-MCP) application, salicylic acid (SA) dipping and their combined treatments during cold storage at $0^{\circ} \mathrm{C}$ for 28 days

\begin{tabular}{|c|c|c|c|c|c|c|c|c|c|}
\hline \multirow{3}{*}{ Pre-storage treatments } & \multicolumn{8}{|c|}{ Storage period (days) } & \multirow{3}{*}{ Mean } \\
\hline & & $\mathbf{0}$ & 7 & 14 & & 21 & & 28 & \\
\hline & \multicolumn{8}{|c|}{ Season 2015} & \\
\hline Distilled water (control) & 1.65 & $\mathrm{a}$ & $1.34 \mathrm{f}-\mathrm{k}$ & 1.051 & 0.88 & $\mathrm{~m}$ & 0.70 & $\mathrm{n}$ & $1.12 \mathrm{D}$ \\
\hline $0.5 \mathrm{ppm} 1-\mathrm{MCP}$ & 1.65 & $\mathrm{a}$ & $1.52 \mathrm{a}-\mathrm{f}$ & $1.42 \mathrm{~b}-\mathrm{g}$ & 1.22 & h-1 & 1.14 & 1 & $1.39 \mathrm{BC}$ \\
\hline 1 ppm 1-MCP & 1.65 & $\mathrm{a}$ & $1.54 \mathrm{a}-\mathrm{e}$ & $1.44 \mathrm{~b}-\mathrm{f}$ & 1.24 & $g-1$ & 1.16 & $\mathrm{kl}$ & $1.41 \mathrm{ABC}$ \\
\hline $0.5 \mathrm{mM} \mathrm{SA}$ & 1.65 & a & $1.50 \mathrm{a}-\mathrm{f}$ & $1.37 \mathrm{~d}-\mathrm{i}$ & 1.18 & $\mathrm{jkl}$ & 1.12 & 1 & $1.36 \mathrm{C}$ \\
\hline $1 \mathrm{mM} \mathrm{SA}$ & 1.65 & a & $1.52 \mathrm{a}-\mathrm{f}$ & $1.39 \mathrm{c}-\mathrm{h}$ & 1.24 & $g-1$ & 1.14 & 1 & $1.39 \mathrm{BC}$ \\
\hline $0.5 \mathrm{ppm} 1-\mathrm{MCP}+0.5 \mathrm{mM} \mathrm{SA}$ & 1.65 & $\mathrm{a}$ & $1.59 \mathrm{abc}$ & $1.48 \mathrm{a}-\mathrm{f}$ & 1.39 & $\mathrm{c}-\mathrm{i}$ & 1.18 & $\mathrm{jkl}$ & $1.46 \mathrm{AB}$ \\
\hline 0.5 ppm 1-MCP + 1 mM SA & 1.65 & $\mathrm{a}$ & $1.61 \mathrm{ab}$ & $1.50 \mathrm{a}-\mathrm{f}$ & 1.44 & $b-f$ & 1.20 & $\mathrm{i}-1$ & $1.48 \mathrm{~A}$ \\
\hline $1 \mathrm{ppm} 1-\mathrm{MCP}+0.5 \mathrm{mM} \mathrm{SA}$ & 1.65 & $\mathrm{a}$ & $1.56 \mathrm{a}-\mathrm{d}$ & $1.44 \mathrm{~b}-\mathrm{f}$ & 1.35 & $e-j$ & 1.16 & $\mathrm{kl}$ & $1.43 \mathrm{ABC}$ \\
\hline 1 ppm 1-MCP + 1 mM SA & 1.65 & $\mathrm{a}$ & $1.56 \mathrm{a}-\mathrm{d}$ & $1.46 \mathrm{a}-\mathrm{f}$ & 1.37 & $\mathrm{~d}-\mathrm{i}$ & 1.18 & $\mathrm{jkl}$ & $1.45 \mathrm{AB}$ \\
\hline \multirow[t]{2}{*}{ Means } & 1.65 & A & $1.53 \mathrm{~B}$ & $1.39 \mathrm{C}$ & 1.26 & $\mathrm{D}$ & 1.11 & $\mathrm{E}$ & \\
\hline & \multicolumn{8}{|c|}{ Season 2016} & \\
\hline Distilled water (control) & 1.59 & $\mathrm{a}$ & $1.25 \mathrm{e}-1$ & $1.03 \mathrm{~m}$ & 0.84 & $\mathrm{n}$ & 0.66 & o & $1.07 \mathrm{~F}$ \\
\hline 0.5 ppm 1-MCP & 1.59 & $\mathrm{a}$ & $1.36 \mathrm{~b}-\mathrm{j}$ & $1.25 \mathrm{e}-1$ & 1.15 & $\mathrm{j}-\mathrm{m}$ & 1.13 & $\mathrm{k} l \mathrm{~m}$ & $1.29 \mathrm{DE}$ \\
\hline 1 ppm 1-MCP & 1.59 & $\mathrm{a}$ & $1.42 \mathrm{a}-\mathrm{f}$ & $1.32 \mathrm{c}-\mathrm{k}$ & 1.19 & $\mathrm{~g}-\mathrm{m}$ & 1.17 & $\mathrm{i}-\mathrm{m}$ & 1.34 B-E \\
\hline $0.5 \mathrm{mM} \mathrm{SA}$ & 1.59 & a & $1.34 \mathrm{~b}-\mathrm{k}$ & $1.23 \mathrm{f}-\mathrm{m}$ & 1.13 & $\mathrm{klm}$ & 1.07 & $\operatorname{lm}$ & $1.27 \mathrm{E}$ \\
\hline $1 \mathrm{mM} \mathrm{SA}$ & 1.59 & $\mathrm{a}$ & $1.40 \mathrm{a}-\mathrm{g}$ & $1.30 \mathrm{~d}-\mathrm{k}$ & 1.17 & $\mathrm{i}-\mathrm{m}$ & 1.15 & $j-m$ & $1.32 \mathrm{CDE}$ \\
\hline $0.5 \mathrm{ppm} 1-\mathrm{MCP}+0.5 \mathrm{mM} \mathrm{SA}$ & 1.59 & $\mathrm{a}$ & $1.51 \mathrm{abc}$ & $1.38 \mathrm{a}-\mathrm{h}$ & 1.33 & $\mathrm{~b}-\mathrm{k}$ & 1.23 & $\mathrm{f}-\mathrm{m}$ & $1.41 \mathrm{AB}$ \\
\hline 0.5 ppm 1-MCP + 1 mM SA & 1.59 & a & $1.53 \mathrm{ab}$ & $1.43 \mathrm{a}-\mathrm{f}$ & 1.37 & $b-i$ & 1.25 & e-1 & $1.43 \mathrm{~A}$ \\
\hline $1 \mathrm{ppm} 1-\mathrm{MCP}+0.5 \mathrm{mM} \mathrm{SA}$ & 1.59 & $\mathrm{a}$ & $1.44 \mathrm{a}-\mathrm{e}$ & $1.36 \mathrm{~b}-\mathrm{i}$ & 1.24 & f-1 & 1.19 & $\mathrm{~h}-\mathrm{m}$ & 1.36 A-D \\
\hline 1 ppm 1-MCP + 1 mM SA & 1.59 & $\mathrm{a}$ & $1.47 \mathrm{a}-\mathrm{d}$ & $1.38 \mathrm{a}-\mathrm{h}$ & 1.28 & $\mathrm{~d}-\mathrm{k}$ & 1.23 & $\mathrm{f}-\mathrm{m}$ & $1.39 \mathrm{ABC}$ \\
\hline Means & 1.59 & A & $1.41 \mathrm{~B}$ & $1.30 \mathrm{C}$ & 1.19 & $\mathrm{D}$ & 1.12 & $\mathrm{E}$ & \\
\hline
\end{tabular}

Means followed by the same letters within pre-storage treatments, storage periods and their interactions in each season are not significantly different at level $P \leq 0.05$ according to DMRT.

The duration of the exposure to 1-MCP and SA dipping were 24 hours and 5 minutes, respectively. 
TABLE 9. Changes in total soluble solids/titratable acidity ratio of 'Canino' apricots treated with exposure to 1-methylcyclopropene (1-MCP) application, salicylic acid (SA) dipping and their combined treatments during cold storage at $0^{\circ} \mathrm{C}$ for 28 days

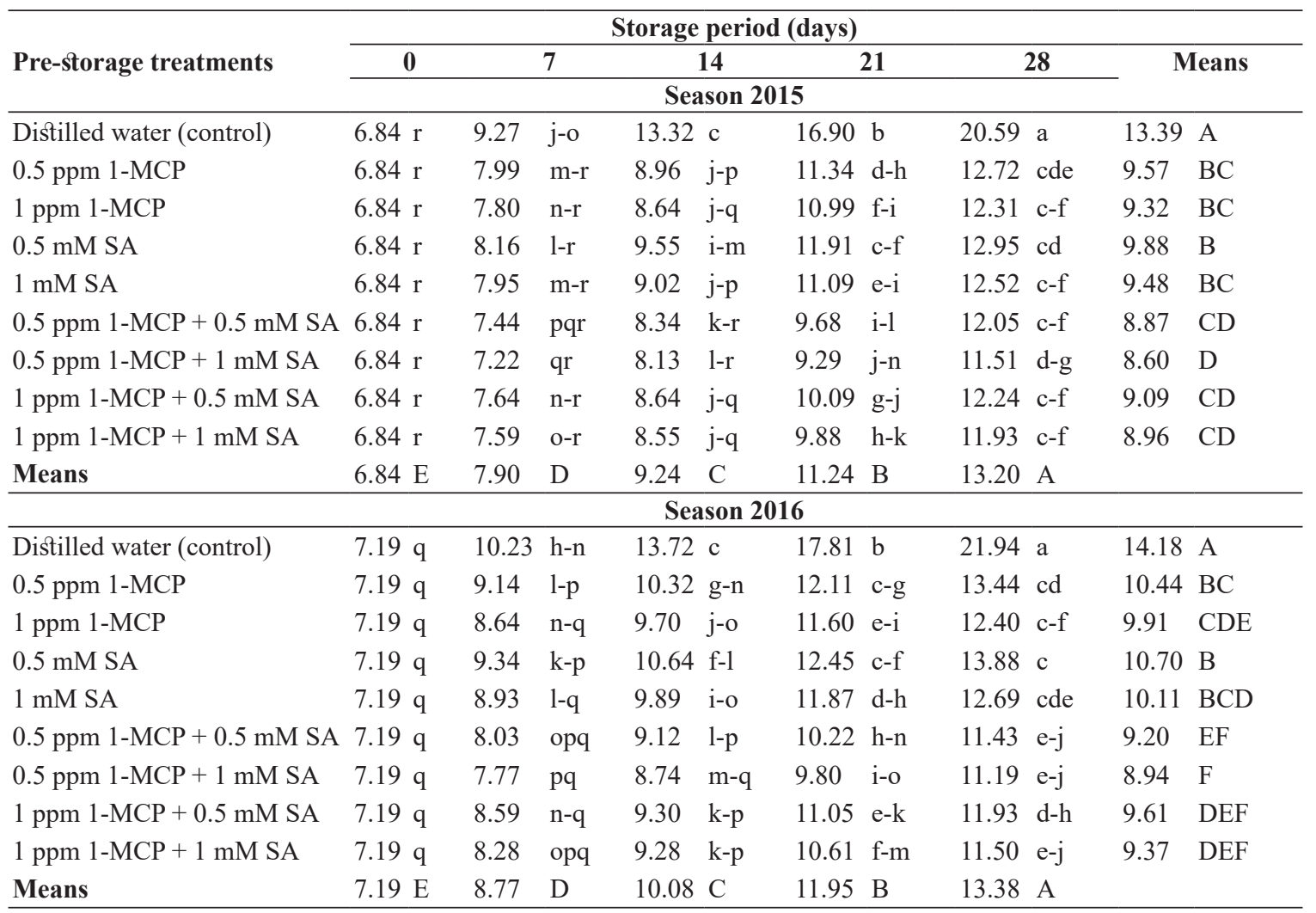

Means followed by the same letters within pre-storage treatments, storage periods and their interactions in each season are not significantly different at level $P \leq 0.05$ according to DMRT.

The duration of the exposure to 1-MCP and SA dipping were 24 hours and 5 minutes, respectively.

TABLE 10. Changes in ascorbic acid (AsA), total soluble solids (TSS), titratable acidity (TA) and TSS/TA ratio contents of 'Canino' apricots treated with exposure to 1-methylcyclopropene (1-MCP) application, salicylic acid (SA) dipping and their combined treatments after cold storage at $0^{\circ} \mathrm{C}$ for 28 days and then transferred to about $25^{\circ} \mathrm{C}$ for 3 days shelf life

\begin{tabular}{|c|c|c|c|c|c|c|c|c|}
\hline \multirow[t]{2}{*}{ Pre-storage treatments } & \multicolumn{2}{|c|}{$\begin{array}{c}\text { AsA } \\
\text { (mg/100 ml juice) }\end{array}$} & \multicolumn{2}{|c|}{ TSS ( ${ }^{\circ}$ Brix) } & \multicolumn{2}{|c|}{\begin{tabular}{|c|} 
TA \\
$\begin{array}{c}\text { (g malic acid } / 100 \\
\text { ml juice })\end{array}$
\end{tabular}} & \multicolumn{2}{|c|}{ TSS/TA ratio } \\
\hline & $\begin{array}{c}\text { Season } \\
2015\end{array}$ & $\begin{array}{c}\text { Season } \\
2016 \\
\end{array}$ & $\begin{array}{c}\text { Season } \\
2015\end{array}$ & $\begin{array}{c}\text { Season } \\
2016 \\
\end{array}$ & $\begin{array}{c}\text { Season } \\
2015\end{array}$ & $\begin{array}{c}\text { Season } \\
2016\end{array}$ & \begin{tabular}{|c|} 
Season \\
2015 \\
\end{tabular} & $\begin{array}{c}\text { Seasor } \\
2016 \\
\end{array}$ \\
\hline Distilled water (control) & $8.89 \mathrm{e}$ & $8.67 \mathrm{e}$ & $13.60 \mathrm{~b}$ & $13.73 \mathrm{~b}$ & $0.49 \mathrm{~b}$ & $0.47 \mathrm{~b}$ & $28.48 \mathrm{a}$ & $29.67 \mathrm{a}$ \\
\hline 0.5 ppm 1-MCP & $10.83 \mathrm{~cd}$ & $10.84 \mathrm{~cd}$ & $13.80 \mathrm{ab}$ & $14.27 \mathrm{a}$ & $0.89 \mathrm{a}$ & $0.83 \mathrm{a}$ & $15.47 \mathrm{~b}$ & $17.42 \mathrm{~b}$ \\
\hline 1 ppm 1-MCP & $11.67 \mathrm{bcd}$ & $11.38 \mathrm{bcd}$ & $13.93 \mathrm{ab}$ & $14.33 \mathrm{a}$ & $0.94 \mathrm{a}$ & $0.87 \mathrm{a}$ & $15.05 \mathrm{~b}$ & $17.49 \mathrm{~b}$ \\
\hline $0.5 \mathrm{mM}$ SA & $10.56 \mathrm{~d}$ & $10.57 \mathrm{~d}$ & $13.73 \mathrm{ab}$ & $14.20 \mathrm{a}$ & $0.87 \mathrm{a}$ & $0.80 \mathrm{a}$ & $15.83 \mathrm{~b}$ & $17.98 \mathrm{~b}$ \\
\hline $1 \mathrm{mM} \mathrm{SA}$ & $11.39 \mathrm{bcd}$ & $11.11 \mathrm{bcd}$ & $13.87 \mathrm{ab}$ & $14.27 \mathrm{a}$ & $0.92 \mathrm{a}$ & $0.85 \mathrm{a}$ & $15.27 \mathrm{~b}$ & $18.35 \mathrm{~b}$ \\
\hline $0.5 \mathrm{ppm} 1-\mathrm{MCP}+0.5 \mathrm{mM} \mathrm{SA}$ & $12.50 \mathrm{ab}$ & $12.47 \mathrm{ab}$ & $14.07 \mathrm{a}$ & $14.07 \mathrm{ab}$ & $1.01 \mathrm{a}$ & $0.98 \mathrm{a}$ & $14.03 \mathrm{~b}$ & $14.50 \mathrm{~b}$ \\
\hline 0.5 ppm 1-MCP + 1 mM SA & $13.06 \mathrm{a}$ & $13.01 \mathrm{a}$ & $14.00 \mathrm{a}$ & $14.13 \mathrm{a}$ & $1.05 \mathrm{a}$ & $1.03 \mathrm{a}$ & $13.47 \mathrm{~b}$ & $13.94 \mathrm{~b}$ \\
\hline $1 \mathrm{ppm} 1-\mathrm{MCP}+0.5 \mathrm{mM} \mathrm{SA}$ & $11.94 \mathrm{abc}$ & $11.92 \mathrm{abcd}$ & $13.93 \mathrm{ab}$ & $14.00 \mathrm{ab}$ & $0.98 \mathrm{a}$ & $0.92 \mathrm{a}$ & $14.20 \mathrm{~b}$ & $15.31 \mathrm{~b}$ \\
\hline 1 ppm 1-MCP + 1 mM SA & $12.22 \mathrm{ab}$ & $12.20 \mathrm{abc}$ & $14.07 \mathrm{a}$ & $14.07 \mathrm{ab}$ & $0.98 \mathrm{a}$ & $0.94 \mathrm{a}$ & $14.49 \mathrm{~b}$ & $15.04 \mathrm{~b}$ \\
\hline
\end{tabular}

Means followed by the same letters in each column for every season are not significantly different according to DMRT at level $P \leq 0.05$. The duration of the exposure to 1-MCP and SA dipping were 24 hours and 5 minutes, respectively. 
apricots contents of AsA and TA with slowed the increase in TSS/TA ratio as compared to control fruits after the end of cold storage (28 days) plus 3 days shelf life at ambient temperature in the two seasons. Moreover, 'Canino' apricots treated with exposure to 0.5 or $1 \mathrm{ppm}$ of $1-\mathrm{MCP}$, dipping in 0.5 or $1 \mathrm{mM}$ of SA and their combination showed the progressive increment in TSS content during shelf life as compared to untreated fruits (control).

The loss in AsA during prolonged storage of fruits seems to be due to the activation of enzymes like ascorbic acid oxidase that oxidized L-ascorbic acid into dehydroascorbic acid (Mapson, 1970). The increasing trends in TSS content of fruit in the initial storage intervals might be due to fruit ripening, while the reduction in this characteristic at later stage of storage may be due to degradation of soluble sugars into alcohols and water as a result of senescence process of fruits (Kays, 1991). The increment amounts of TSS over the storage period could be due to the increasing in fruit weight loss (Ezzat, 2014). The decreasing patterns in TA during storage in the current study may be due to a reduction in the organic acids consumption or their conversion to sugars during respiratory metabolism and utilized by different enzymatic activities (Jan and Rab, 2012). In addition, SA is effectively protected the cell walls by decreasing the degrading enzymes and consequence prevented the increase in TSS content of the cells (Asghari and Aghdam, 2010 and Ezzat, 2014).

Our results are in similarity with the findings of Dong et al. (2002) on 'Canino' apricots and 'Royal Zee' plums, Liu et al. (2005) and Tareen et al., (2012a, b) on peaches, Erkan and Eski (2012) on plums and Shi et al., (2013), Ezzat (2014) and Moradinezhad and Jahani (2016) on apricots. In addition, these results are in line with those obtained by Mohamed et al., (2016a) on oranges, Mohamed et al. (2016b) on mangoes and Özkaya et al. (2016) on nectarine fruits. They reported that, treated fruits with exposure to 1-MCP or SA dipping reduced losses in AsA and TA as well as constricted the changing rate of TSS and TSS/ TA ratio as compared to untreated fruits (control) during storage.

Fruit contents in total chlorophyll, total carotenoids and total phenolic

Data tabulated in Tables 11 and 12 illustrate that, pre-storage treatments with exposure of 'Canino' apricots to 0.5 or 1 ppm of $1-\mathrm{MCP}, \mathrm{SA}$

Egypt. J. Hort. Vol. 45, No.1 (2018) dipping at 0.5 or $1 \mathrm{mM}$ concentration and their combined application significantly delayed colour development of apricots. Therefore, treated fruits had greener than untreated fruits (control). Interestingly, 'Canino' apricots fruits exposed to a concentration of $0.5 \mathrm{ppm} 1-\mathrm{MCP}$ then its dipping in $\mathrm{SA}$ at $1 \mathrm{mM}$ concentration constricting the changing rate of colour and showed maximum retention in total chlorophyll content $(3.98 \& 3.87$ $\mathrm{mg} / 100 \mathrm{~g} \mathrm{FW})$ and minimum total carotenoids content ( $1.71 \& 1.75 \mathrm{mg} / 100 \mathrm{~g} \mathrm{FW})$ in 2015 and 2016 seasons, respectively. These results indicate that, untreated 'Canino' apricots (control) turned to completely yellow because of hastened ripening process. On the other side, data in Table 13 reveal that, total phenolic content of 'Canino' apricots significantly increased in all treated apricot fruits especially combined treatments than control fruits during the two seasons. Moreover, maximum total phenolic content $(61.21 \& 61.52 \mathrm{mg}$ gallic $\mathrm{acid} / 100 \mathrm{~g} \mathrm{FW}$ ) was observed in exposure apricots to $0.5 \mathrm{ppm}$ of 1-MCP then its dipping in SA at 1 $\mathrm{mM}$ concentration in the first and second seasons, respectively. In untreated fruits (control), total carotenoids and total phenolic contents increased up to 14 and 21 days, respectively at $0^{\circ} \mathrm{C}$ then decreased till end of cold storage period (Tables 12 and 13). In this concern, untreated fruits (control) recorded the minimum retention of fruit content in total chlorophyll $(2.58 \& 2.27 \mathrm{mg} / 100 \mathrm{~g} \mathrm{FW})$ and maximum total carotenoids content $(1.81 \& 1.84$ $\mathrm{mg} / 100 \mathrm{~g} \mathrm{FW})$ as well as recorded the minimum total phenolic content $(54.69 \& 53.79 \mathrm{mg}$ gallic $\mathrm{acid} / 100 \mathrm{~g} \mathrm{FW}$ ) in the first and second seasons, respectively.

As for the effect of storage period, variability in colour of 'Canino' apricots from yellowish green to yellow increased with advanced of cold storage period in both seasons under this study. In this concern, the minimal chlorophyll content (2.99 \& $2.85 \mathrm{mg} / 100 \mathrm{~g} \mathrm{FW}$ ) and maximal total carotenoids content $(1.86 \& 1.89 \mathrm{mg} / 100 \mathrm{~g} \mathrm{FW})$ in apricots were observed after 28 days at $0^{\circ} \mathrm{C}$ in the first and second seasons, respectively (Tables 11 and 12). On the other hand, total phenolic content of apricots showed an increase during initial stages of cold storage at $0^{\circ} \mathrm{C}$ up to 21 days $(63.94$ \& $63.58 \mathrm{mg}$ gallic acid/100 g FW) followed by a decline up to the end of cold storage period (60.44 \& $60.64 \mathrm{mg}$ gallic acid/100 g FW) in 2015 and 2016 seasons, respectively.

Referring to the interaction effect, significant differences were found between pre-storage 
TABLE 11. Changes in total chlorophyll content $(\mathrm{mg} / 100 \mathrm{~g} \mathrm{FW})$ of 'Canino' apricots treated with exposure to 1-methylcyclopropene (1-MCP) application, salicylic acid (SA) dipping and their combined treatments during cold storage at $0^{\circ} \mathrm{C}$ for 28 days

\begin{tabular}{|c|c|c|c|c|c|c|c|c|c|c|c|}
\hline \multirow{3}{*}{ Pre-storage treatments } & \multicolumn{9}{|c|}{ Storage period (days) } & \multirow{3}{*}{\multicolumn{2}{|c|}{ Means }} \\
\hline & & $\mathbf{0}$ & & 7 & & 14 & 21 & & 28 & & \\
\hline & \multicolumn{9}{|c|}{ Season 2015} & & \\
\hline Distilled water (control) & 4.35 & $\mathrm{a}$ & 2.87 & $\mathrm{q}$ & 2.55 & $\mathrm{r}$ & $1.87 \mathrm{~s}$ & 1.26 & $\mathrm{t}$ & 2.58 & $\mathrm{~F}$ \\
\hline 0.5 ppm 1-MCP & 4.35 & $\mathrm{a}$ & 3.78 & $e-j$ & 3.61 & $\mathrm{jkl}$ & $3.32 \mathrm{~m}$ & 3.04 & opq & 3.62 & $\mathrm{DE}$ \\
\hline 1 ppm 1-MCP & 4.35 & $\mathrm{a}$ & 3.93 & $c-g$ & 3.69 & h-k & $3.41 \mathrm{~lm}$ & 3.11 & nop & 3.70 & $\mathrm{CD}$ \\
\hline $0.5 \mathrm{mM} \mathrm{SA}$ & 4.35 & $\mathrm{a}$ & 3.75 & $\mathrm{f}-\mathrm{k}$ & 3.57 & $\mathrm{jkl}$ & $3.27 \mathrm{mn}$ & 2.97 & $\mathrm{pq}$ & 3.58 & $\mathrm{E}$ \\
\hline $1 \mathrm{mM} \mathrm{SA}$ & 4.35 & $\mathrm{a}$ & 3.89 & d-h & 3.66 & $\mathrm{ijk}$ & $3.40 \mathrm{~lm}$ & 3.09 & nop & 3.68 & $\mathrm{D}$ \\
\hline $0.5 \mathrm{ppm} 1-\mathrm{MCP}+0.5 \mathrm{mM} \mathrm{SA}$ & 4.35 & $\mathrm{a}$ & 4.12 & bc & 3.88 & d-h & $3.73 \mathrm{~g}-\mathrm{k}$ & 3.41 & $\operatorname{lm}$ & 3.90 & A \\
\hline $0.5 \mathrm{ppm} 1-\mathrm{MCP}+1 \mathrm{mM} \mathrm{SA}$ & 4.35 & $\mathrm{a}$ & 4.21 & $a b$ & 3.95 & $c-f$ & $3.82 \mathrm{e}-\mathrm{i}$ & 3.57 & $\mathrm{jkl}$ & 3.98 & A \\
\hline $1 \mathrm{ppm} 1-\mathrm{MCP}+0.5 \mathrm{mM} \mathrm{SA}$ & 4.35 & $\mathrm{a}$ & 3.98 & cde & 3.74 & $\mathrm{f}-\mathrm{k}$ & $3.55 \mathrm{kl}$ & 3.22 & mno & 3.77 & $\mathrm{BC}$ \\
\hline 1 ppm 1-MCP + 1 mM SA & 4.35 & $\mathrm{a}$ & 4.04 & bed & 3.76 & $\mathrm{f}-\mathrm{k}$ & $3.63 \mathrm{ijk}$ & 3.25 & $\mathrm{mn}$ & 3.81 & B \\
\hline \multirow[t]{2}{*}{ Means } & \multirow{2}{*}{\multicolumn{9}{|c|}{$\begin{array}{ccc}3.60 \mathrm{C} & 3.33 \mathrm{D} \\
\text { Season } \mathbf{2 0 1 6}\end{array}$}} & & \\
\hline & & & & & & & & & & & \\
\hline Distilled water (control) & 4.17 & $\mathrm{a}$ & 2.56 & $\mathrm{p}$ & 2.26 & $q$ & $1.38 \mathrm{r}$ & 0.96 & $\mathrm{~s}$ & 2.27 & $\mathrm{E}$ \\
\hline $0.5 \mathrm{ppm} 1-\mathrm{MCP}$ & 4.17 & $\mathrm{a}$ & 3.70 & $e-i$ & 3.53 & $\mathrm{ij}$ & $3.15 \mathrm{kl}$ & 2.81 & no & 3.47 & $\mathrm{D}$ \\
\hline $1 \mathrm{ppm} 1-\mathrm{MCP}$ & 4.17 & $\mathrm{a}$ & 3.84 & $b-f$ & 3.70 & e-i & $3.29 \mathrm{k}$ & 3.02 & $\operatorname{lm}$ & 3.61 & $\mathrm{C}$ \\
\hline $0.5 \mathrm{mM}$ SA & 4.17 & $\mathrm{a}$ & 3.66 & $f-j$ & 3.48 & $\mathrm{j}$ & $3.12 \mathrm{kl}$ & 2.75 & o & 3.44 & $\mathrm{D}$ \\
\hline $1 \mathrm{mM} \mathrm{SA}$ & 4.17 & $\mathrm{a}$ & 3.80 & $c-f$ & 3.66 & $f-j$ & $3.24 \mathrm{k}$ & 2.93 & $\mathrm{mn}$ & 3.56 & $\mathrm{C}$ \\
\hline $0.5 \mathrm{ppm} 1-\mathrm{MCP}+0.5 \mathrm{mM} \mathrm{SA}$ & 4.17 & $\mathrm{a}$ & 3.94 & $\mathrm{bc}$ & 3.77 & $\mathrm{c}-\mathrm{g}$ & $3.59 \mathrm{~g}-\mathrm{j}$ & 3.26 & $\mathrm{k}$ & 3.75 & $\mathrm{~B}$ \\
\hline $0.5 \mathrm{ppm} 1-\mathrm{MCP}+1 \mathrm{mM} \mathrm{SA}$ & 4.17 & $\mathrm{a}$ & 4.02 & $\mathrm{ab}$ & 3.88 & b-e & $3.73 \mathrm{~d}-\mathrm{i}$ & 3.56 & hij & 3.87 & A \\
\hline $1 \mathrm{ppm} 1-\mathrm{MCP}+0.5 \mathrm{mM} \mathrm{SA}$ & 4.17 & $\mathrm{a}$ & 3.89 & b-e & 3.71 & $e-i$ & $3.49 \mathrm{j}$ & 3.15 & $\mathrm{kl}$ & 3.68 & $\mathrm{~B}$ \\
\hline 1 ppm $1-\mathrm{MCP}+1 \mathrm{mM} \mathrm{SA}$ & 4.17 & $\mathrm{a}$ & 3.92 & bcd & 3.75 & $\mathrm{c}-\mathrm{h}$ & $3.54 \mathrm{ij}$ & 3.20 & $\mathrm{k} 1$ & 3.72 & $\mathrm{~B}$ \\
\hline Means & 4.17 & A & 3.70 & B & 3.53 & $\mathrm{C}$ & $3.17 \mathrm{D}$ & 2.85 & $\mathrm{E}$ & & \\
\hline
\end{tabular}

Means followed by the same letters within pre-storage treatments, storage periods and their interactions in each season are not significantly different at level $P \leq 0.05$ according to DMRT.

The duration of the exposure to 1-MCP and SA dipping were 24 hours and 5 minutes, respectively.

TABLE 12. Changes in total carotenoids content $(\mathrm{mg} / 100 \mathrm{~g} \mathrm{FW})$ of 'Canino' apricots treated with exposure to 1-methylcyclopropene (1-MCP) application, salicylic acid (SA) dipping and their combined treatments during cold storage at $0^{\circ} \mathrm{C}$ for 28 days

\begin{tabular}{|c|c|c|c|c|c|c|c|c|}
\hline \multirow{3}{*}{ Pre-storage treatments } & \multicolumn{7}{|c|}{ Storage period (days) } & \multirow{3}{*}{ Means } \\
\hline & & $\mathbf{0}$ & & 7 & 14 & 21 & 28 & \\
\hline & \multicolumn{7}{|c|}{ Season 2015} & \\
\hline Distilled water (control) & 1.62 & $\mathrm{~m}$ & 1.84 & $a-f$ & $1.90 \mathrm{ab}$ & $1.87 \mathrm{a}-\mathrm{d}$ & $1.83 \mathrm{a}-\mathrm{f}$ & $1.81 \mathrm{~A}$ \\
\hline 0.5 ppm 1-MCP & 1.62 & $\mathrm{~m}$ & 1.74 & e-1 & $1.80 \mathrm{a}-\mathrm{j}$ & $1.88 \mathrm{ab}$ & $1.92 \mathrm{a}$ & $1.79 \mathrm{ABC}$ \\
\hline 1 ppm 1-MCP & 1.62 & $\mathrm{~m}$ & 1.69 & $\mathrm{i}-\mathrm{m}$ & $1.75 \mathrm{~d}-1$ & $1.83 \mathrm{a}-\mathrm{f}$ & $1.87 \mathrm{a}-\mathrm{d}$ & $1.75 \mathrm{BCD}$ \\
\hline 0.5 mM SA & 1.62 & $\mathrm{~m}$ & 1.75 & d-1 & $1.81 \mathrm{a}-\mathrm{i}$ & $1.89 \mathrm{ab}$ & $1.91 \mathrm{a}$ & $1.80 \mathrm{AB}$ \\
\hline $1 \mathrm{mM} \mathrm{SA}$ & 1.62 & $\mathrm{~m}$ & 1.701 & h-m & $1.75 \mathrm{c}-1$ & $1.84 \mathrm{a}-\mathrm{f}$ & $1.87 \mathrm{abc}$ & $1.76 \mathrm{BCD}$ \\
\hline $0.5 \mathrm{ppm} 1-\mathrm{MCP}+0.5 \mathrm{mM} \mathrm{SA}$ & 1.62 & $\mathrm{~m}$ & 1.661 & $\mathrm{klm}$ & $1.72 \mathrm{f}-\mathrm{m}$ & $1.80 \mathrm{a}-\mathrm{j}$ & $1.84 \mathrm{a}-\mathrm{f}$ & $1.73 \mathrm{D}$ \\
\hline 0.5 ppm 1-MCP + 1 mM SA & 1.62 & $\mathrm{~m}$ & 1.64 & $\operatorname{lm}$ & $1.70 \mathrm{~g}-\mathrm{m}$ & $1.78 \mathrm{~b}-\mathrm{k}$ & $1.82 \mathrm{a}-\mathrm{g}$ & $1.71 \mathrm{D}$ \\
\hline $1 \mathrm{ppm} 1-\mathrm{MCP}+0.5 \mathrm{mM} \mathrm{SA}$ & 1.62 & $\mathrm{~m}$ & 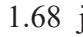 & $\mathrm{j}-\mathrm{m}$ & 1.74 e-m & $1.82 \mathrm{a}-\mathrm{h}$ & $1.86 \mathrm{a}-\mathrm{e}$ & $1.74 \mathrm{CD}$ \\
\hline 1 ppm 1-MCP + 1 mM SA & 1.62 & $\mathrm{~m}$ & $1.67 \mathrm{i}$ & $\mathrm{klm}$ & $1.72 \mathrm{f}-\mathrm{m}$ & $1.81 \mathrm{a}-\mathrm{i}$ & $1.84 \mathrm{a}-\mathrm{f}$ & $1.73 \mathrm{D}$ \\
\hline \multirow[t]{2}{*}{ Means } & 1.62 & $\mathrm{D}$ & 1.71 & $\mathrm{C}$ & $1.76 \mathrm{~B}$ & $1.84 \mathrm{~A}$ & $1.86 \mathrm{~A}$ & \\
\hline & \multicolumn{7}{|c|}{ Season 2016} & \\
\hline Distilled water (control) & 1.65 & $\mathrm{~h}$ & 1.90 & $\mathrm{ab}$ & $1.94 \mathrm{a}$ & 1.86 a-f & $1.84 \mathrm{a}-\mathrm{g}$ & $1.84 \mathrm{~A}$ \\
\hline 0.5 ppm 1-MCP & 1.65 & $\mathrm{~h}$ & 1.81 & $\mathrm{a}-\mathrm{g}$ & $1.84 \mathrm{a}-\mathrm{g}$ & $1.90 \mathrm{abc}$ & $1.94 \mathrm{a}$ & $1.83 \mathrm{AB}$ \\
\hline 1 ppm 1-MCP & 1.65 & $\mathrm{~h}$ & 1.76 & $\mathrm{c}-\mathrm{h}$ & $1.79 \mathrm{~b}-\mathrm{h}$ & $1.84 \mathrm{a}-\mathrm{g}$ & $1.89 \mathrm{a}-\mathrm{d}$ & $1.79 \mathrm{ABC}$ \\
\hline $0.5 \mathrm{mM} \mathrm{SA}$ & 1.65 & $\mathrm{~h}$ & 1.82 & $\mathrm{a}-\mathrm{g}$ & $1.85 \mathrm{a}-\mathrm{g}$ & $1.90 \mathrm{abc}$ & $1.95 \mathrm{a}$ & $1.83 \mathrm{AB}$ \\
\hline $1 \mathrm{mM} \mathrm{SA}$ & 1.65 & $\mathrm{~h}$ & 1.76 & $\mathrm{~b}-\mathrm{h}$ & $1.79 \mathrm{~b}-\mathrm{g}$ & $1.85 \mathrm{a}-\mathrm{g}$ & $1.90 \mathrm{abc}$ & $1.79 \mathrm{ABC}$ \\
\hline $0.5 \mathrm{ppm} 1-\mathrm{MCP}+0.5 \mathrm{mM}$ SA & 1.65 & $\mathrm{~h}$ & 1.73 & fgh & $1.76 \mathrm{~b}-\mathrm{h}$ & $1.82 \mathrm{a}-\mathrm{g}$ & $1.86 \mathrm{a}-\mathrm{f}$ & $1.76 \mathrm{C}$ \\
\hline $0.5 \mathrm{ppm} 1-\mathrm{MCP}+1 \mathrm{mM} \mathrm{SA}$ & 1.65 & $\mathrm{~h}$ & 1.71 & $\mathrm{gh}$ & $1.74 \mathrm{e}-\mathrm{h}$ & $1.80 \mathrm{~b}-\mathrm{g}$ & $1.84 \mathrm{a}-\mathrm{g}$ & $1.75 \mathrm{C}$ \\
\hline $1 \mathrm{ppm} 1-\mathrm{MCP}+0.5 \mathrm{mM} \mathrm{SA}$ & 1.65 & $\mathrm{~h}$ & 1.75 & d-h & $1.78 \mathrm{~b}-\mathrm{h}$ & $1.83 \mathrm{a}-\mathrm{g}$ & 1.88 a-e & $1.78 \mathrm{BC}$ \\
\hline 1 ppm 1-MCP + 1 mM SA & 1.65 & $\mathrm{~h}$ & 1.73 & fgh & $1.76 \mathrm{~b}-\mathrm{h}$ & $1.82 \mathrm{a}-\mathrm{g}$ & $1.87 \mathrm{a}-\mathrm{f}$ & $1.77 \mathrm{C}$ \\
\hline Means & 1.65 & $\mathrm{D}$ & 1.77 & $\mathrm{C}$ & $1.81 \mathrm{BC}$ & $1.85 \mathrm{~B}$ & $1.89 \mathrm{~A}$ & \\
\hline
\end{tabular}

Means followed by the same letters within pre-storage treatments, storage periods and their interactions in each season are not significantly different at level $P \leq 0.05$ according to DMRT.

The duration of the exposure to 1-MCP and SA dipping were 24 hours and 5 minutes, respectively. 
TABLE 13. Changes in total phenolic content ( $\mathrm{mg}$ gallic acid/100 $\mathrm{g} \mathrm{FW}$ ) of 'Canino' apricots treated with exposure to 1-methylcyclopropene (1-MCP) application, salicylic acid (SA) dipping and their combined treatments during cold storage at $0^{\circ} \mathrm{C}$ for 28 days

\begin{tabular}{|c|c|c|c|c|c|c|c|}
\hline \multirow{3}{*}{ Pre-storage treatments } & \multicolumn{6}{|c|}{ Storage period (days) } & \multirow{3}{*}{ Means } \\
\hline & $\mathbf{0}$ & 0 & 7 & 14 & 21 & 28 & \\
\hline & \multicolumn{6}{|c|}{ Season 2015} & \\
\hline Distilled water (control) & $49.07 \mathrm{q}$ & & $55.92 \mathrm{o}$ & 59.10 i-o & 56.85 no & $52.49 \mathrm{p}$ & $54.69 \mathrm{E}$ \\
\hline 0.5 ppm 1-MCP & $49.07 \mathrm{q}$ & & 56.79 no & $61.51 \mathrm{e}-1$ & $63.27 \mathrm{~b}-\mathrm{g}$ & $58.85 \mathrm{j}-\mathrm{o}$ & $57.90 \mathrm{CD}$ \\
\hline 1 ppm 1-MCP & $49.07 \mathrm{q}$ & $\mathrm{q}$ & 57.44 no & $61.95 \mathrm{c}-\mathrm{k}$ & $65.53 \mathrm{abc}$ & $59.95 \mathrm{f}-\mathrm{n}$ & $58.79 \mathrm{BC}$ \\
\hline $0.5 \mathrm{mM}$ SA & $49.07 \mathrm{q}$ & $\mathrm{q}$ & 56.28 no & $61.21 \mathrm{e}-\mathrm{m}$ & $62.51 \mathrm{c}-\mathrm{i}$ & 56.82 no & $57.18 \mathrm{D}$ \\
\hline $1 \mathrm{mM} \mathrm{SA}$ & $49.07 \mathrm{q}$ & $\mathrm{q}$ & 57.14 no & $61.64 \mathrm{~d}-1$ & 64.08 a-e & $59.22 \mathrm{~h}-\mathrm{o}$ & $58.23 \mathrm{CD}$ \\
\hline $0.5 \mathrm{ppm} 1-\mathrm{MCP}+0.5 \mathrm{mM} \mathrm{SA}$ & $49.07 \mathrm{q}$ & $\mathrm{q}$ & $58.37 \mathrm{k}-\mathrm{o}$ & $62.76 \mathrm{c}-\mathrm{h}$ & $65.50 \mathrm{abc}$ & 64.20 a-e & $59.98 \mathrm{AB}$ \\
\hline 0.5 ppm 1-MCP + 1 mM SA & $49.07 \mathrm{q}$ & $\mathrm{q}$ & $59.65 \mathrm{~g}-\mathrm{n}$ & $63.49 \mathrm{~b}-\mathrm{f}$ & $67.23 \mathrm{a}$ & $66.60 \mathrm{ab}$ & $61.21 \mathrm{~A}$ \\
\hline $1 \mathrm{ppm} 1-\mathrm{MCP}+0.5 \mathrm{mM} \mathrm{SA}$ & $49.07 \mathrm{q}$ & $\mathrm{q}$ & $57.91 \mathrm{mno}$ & $62.46 \mathrm{c}-\mathrm{j}$ & $65.22 \mathrm{a}-\mathrm{d}$ & $62.04 \mathrm{c}-\mathrm{j}$ & $59.34 \mathrm{BC}$ \\
\hline 1 ppm 1-MCP + 1 mM SA & $49.07 \mathrm{q}$ & $\mathrm{q}$ & $58.101-0$ & $62.63 \mathrm{c}-\mathrm{i}$ & $65.30 \mathrm{a}-\mathrm{d}$ & 63.81 a-e & $59.78 \mathrm{AB}$ \\
\hline \multirow[t]{2}{*}{ Means } & $49.07 \mathrm{E}$ & $\mathrm{E}$ & $57.51 \mathrm{D}$ & $61.86 \mathrm{~B}$ & $63.94 \mathrm{~A}$ & $60.44 \mathrm{C}$ & \\
\hline & \multicolumn{6}{|c|}{ Season 2016} & \\
\hline Distilled water (control) & $50.39 \mathrm{n}$ & $\mathrm{n}$ & $55.22 \mathrm{~lm}$ & 58.41 i-1 & $54.35 \mathrm{~m}$ & $50.56 \mathrm{n}$ & $53.79 \mathrm{~F}$ \\
\hline 0.5 ppm 1-MCP & $50.39 \mathrm{n}$ & $\mathrm{n}$ & $56.16 \mathrm{~lm}$ & 61.74 e-h & $63.48 \mathrm{~b}-\mathrm{g}$ & $59.46 \mathrm{~h}-\mathrm{k}$ & $58.25 \mathrm{DE}$ \\
\hline 1 ppm 1-MCP & $50.39 \mathrm{n}$ & $\mathrm{n}$ & $56.81 \mathrm{klm}$ & $62.72 \mathrm{c}-\mathrm{h}$ & $64.41 \mathrm{a}-\mathrm{e}$ & $60.72 \mathrm{f}-\mathrm{i}$ & $59.01 \mathrm{BCD}$ \\
\hline $0.5 \mathrm{mM}$ SA & $50.39 \mathrm{n}$ & $\mathrm{n}$ & $56.02 \mathrm{~lm}$ & $60.11 \mathrm{~g}-\mathrm{j}$ & $62.39 \mathrm{c}-\mathrm{h}$ & $57.37 \mathrm{j}-\mathrm{m}$ & $57.26 \mathrm{E}$ \\
\hline $1 \mathrm{mM} \mathrm{SA}$ & $50.39 \mathrm{n}$ & $\mathrm{n}$ & $56.51 \mathrm{klm}$ & $62.53 \mathrm{c}-\mathrm{h}$ & 64.29 a-e & $60.27 \mathrm{~g}-\mathrm{j}$ & $58.80 \mathrm{CD}$ \\
\hline $0.5 \mathrm{ppm} 1-\mathrm{MCP}+0.5 \mathrm{mM} \mathrm{SA}$ & $50.39 \mathrm{n}$ & $\mathrm{n}$ & 58.08 i-1 & $62.99 \mathrm{~b}-\mathrm{g}$ & $65.71 \mathrm{abc}$ & 64.69 a-e & $60.37 \mathrm{AB}$ \\
\hline 0.5 ppm 1-MCP + 1 mM SA & $50.39 \mathrm{n}$ & $\mathrm{n}$ & $59.52 \mathrm{~h}-\mathrm{k}$ & $63.88 \mathrm{~b}-\mathrm{f}$ & $67.50 \mathrm{a}$ & $66.32 \mathrm{ab}$ & $61.52 \mathrm{~A}$ \\
\hline $1 \mathrm{ppm} 1-\mathrm{MCP}+0.5 \mathrm{mM} \mathrm{SA}$ & $50.39 \mathrm{n}$ & $\mathrm{n}$ & $57.40 \mathrm{j}-\mathrm{m}$ & $62.19 \mathrm{~d}-\mathrm{h}$ & 64.93 a-e & $62.91 \mathrm{c}-\mathrm{g}$ & $59.56 \mathrm{BCD}$ \\
\hline 1 ppm 1-MCP + 1 mM SA & $50.39 \mathrm{n}$ & $\mathrm{n}$ & $57.47 \mathrm{i}-\mathrm{m}$ & $62.53 \mathrm{c}-\mathrm{h}$ & 65.17 a-d & $63.49 \mathrm{~b}-\mathrm{g}$ & $59.81 \mathrm{BC}$ \\
\hline Means & $50.39 \mathrm{E}$ & $\mathrm{E}$ & $57.02 \mathrm{D}$ & $61.90 \mathrm{~B}$ & $63.58 \mathrm{~A}$ & $60.64 \mathrm{C}$ & \\
\hline
\end{tabular}

Means followed by the same letters within pre-storage treatments, storage periods and their interactions in each season are not significantly different at level $P \leq 0.05$ according to DMRT.

The duration of the exposure to 1-MCP and SA dipping were 24 hours and 5 minutes, respectively.

TABLE 14. Changes in total chlorophyll, total carotenoids and total phenolic contents of 'Canino' apricots treated with exposure to 1-methylcyclopropene (1-MCP) application, salicylic acid (SA) dipping and their combined treatments after cold storage at $0^{\circ} \mathrm{C}$ for 28 days and then transferred to about $25^{\circ} \mathrm{C}$ for 3 days shelf life

\begin{tabular}{|c|c|c|c|c|c|c|}
\hline \multirow[t]{2}{*}{ Pre-storage treatments } & \multicolumn{2}{|c|}{$\begin{array}{l}\text { Total chlorophyll content } \\
(\mathrm{mg} / 100 \mathrm{~g} \mathrm{FW})\end{array}$} & \multicolumn{2}{|c|}{$\begin{array}{l}\text { Total carotenoids content } \\
\qquad(\mathrm{mg} / \mathbf{1 0 0} \mathrm{g} \mathrm{FW})\end{array}$} & \multicolumn{2}{|c|}{$\begin{array}{c}\text { Total phenolic content } \\
\text { (mg gallic acid/100 g FW) }\end{array}$} \\
\hline & Season 2015 & Season 2016 & Season 2015 & Season 2016 & Season 2015 & Season 2016 \\
\hline Distilled water (control) & $0.73 \mathrm{f}$ & $0.61 \mathrm{f}$ & $1.80 \mathrm{c}$ & $1.82 \mathrm{~b}$ & $48.54 \mathrm{e}$ & $46.25 \mathrm{f}$ \\
\hline 0.5 ppm 1-MCP & $2.74 \mathrm{de}$ & $2.44 \mathrm{de}$ & $1.95 \mathrm{a}$ & $1.95 \mathrm{a}$ & $54.53 \mathrm{~d}$ & $54.94 \mathrm{~d}$ \\
\hline 1 ppm 1-MCP & $2.87 \mathrm{~d}$ & $2.60 \mathrm{~d}$ & $1.93 \mathrm{ab}$ & $1.94 \mathrm{a}$ & $55.63 \mathrm{~cd}$ & $55.37 \mathrm{~d}$ \\
\hline $0.5 \mathrm{mM}$ SA & $2.70 \mathrm{e}$ & $2.41 \mathrm{e}$ & $1.96 \mathrm{a}$ & $1.96 \mathrm{a}$ & $52.50 \mathrm{de}$ & $53.02 \mathrm{e}$ \\
\hline $1 \mathrm{mM} \mathrm{SA}$ & $2.85 \mathrm{~d}$ & $2.52 \mathrm{de}$ & $1.94 \mathrm{ab}$ & $1.94 \mathrm{a}$ & $54.90 \mathrm{~d}$ & $55.25 \mathrm{~d}$ \\
\hline $0.5 \mathrm{ppm} 1-\mathrm{MCP}+0.5 \mathrm{mM} \mathrm{SA}$ & $3.14 \mathrm{~b}$ & $2.95 \mathrm{~b}$ & $1.91 \mathrm{ab}$ & $1.95 \mathrm{a}$ & $61.83 \mathrm{ab}$ & $62.67 \mathrm{~b}$ \\
\hline 0.5 ppm 1-MCP + 1 mM SA & $3.27 \mathrm{a}$ & $3.16 \mathrm{a}$ & $1.89 \mathrm{~b}$ & $1.93 \mathrm{a}$ & $64.89 \mathrm{a}$ & $64.73 \mathrm{a}$ \\
\hline $1 \mathrm{ppm} 1-\mathrm{MCP}+0.5 \mathrm{mM} \mathrm{SA}$ & $3.00 \mathrm{c}$ & $2.78 \mathrm{c}$ & $1.92 \mathrm{ab}$ & $1.96 \mathrm{a}$ & $59.17 \mathrm{bc}$ & $59.82 \mathrm{c}$ \\
\hline 1 ppm 1-MCP + 1 mM SA & $3.07 \mathrm{bc}$ & $2.82 \mathrm{bc}$ & $1.91 \mathrm{ab}$ & $1.95 \mathrm{a}$ & $60.94 \mathrm{ab}$ & $60.09 \mathrm{c}$ \\
\hline
\end{tabular}

Means followed by the same letters in each column for every season are not significantly different according to DMRT at level $P \leq 0.05$. The duration of the exposure to 1-MCP and SA dipping were 24 hours and 5 minutes, respectively. 
treatments and storage periods at $p \leq 0.05$ for total chlorophyll, total carotenoids and total phenolic contents of 'Canino' apricots in the two seasons under this study.

As shown in Table 14, data reveal that, all studied pre-storage treatments significantly reduced the deterioration of total chlorophyll, total carotenoids and total phenolic contents as compared to control fruits at the end of storage at $0^{\circ} \mathrm{C}$ ( 28 days) plus 3 days shelf life at ambient temperature in both seasons. In addition, treated 'Canino' apricots with $0.5 \mathrm{ppm}$ of $1-\mathrm{MCP}$ then its dipping in $\mathrm{SA}$ at $1 \mathrm{mM}$ was the most effective treatment in constricting these changes during shelf life in the two seasons. However, a continuous decrease in total phenolic content was noticed in all treatments including control after 28 days at $0^{\circ} \mathrm{C}$ plus 3 days shelf life at ambient temperature in both seasons.

The loss of chlorophyll content attributed to the breakdown of the chlorophyll structure and increases in chlorophyllase enzyme activity of pigments (Wills et al., 1998). In this research, the higher colour retention of 'Canino' apricots treated with either 0.5 or $1 \mathrm{ppm}$ of $1-\mathrm{MCP}$, dipped in SA at either 0.5 or $1 \mathrm{mM}$ and especially their combined treatments could be attributed to slowing the change of chlorophyll into carotenoids during storage by the reduction of chlorophyll degrading enzyme activities (Cheng et al., 2012). While the decline in total carotenoids content of apricots in control fruit might be due to the fruit senescence as documented by (De Rigal et al., 2000). Moreover, 1-MCP and SA treatments acts as an efficient ethylene antagonist persist for a long time and it can delay the peaks of respiration and ethylene production, thus slow down the ripening process of fruits (Sisler and Serek, 1997 and Srivastava and Dwivedi, 2000). Therefore, treated apricots with 1-MCP, SA and especially combination treatments constricted the variability in colour of 'Canino' apricots by slowed down ripening process during storage. The reduction of phenolic compounds at the end of storage might be attributing to breakdown of cell structure at senescence stage of fruit (Macheix et al., 1990).

In apricots, 1-MCP treatment exhibited less colour change by significantly delayed chlorophyll breakdown and treated fruits were greener than untreated fruits (Fan et al., 2000). Moreover, $1-\mathrm{MCP}$ treatments at different doses $(0.25$ to 1 $\mu \mathrm{L} / \mathrm{L})$ were effective in delaying fruit colour development of apricots during cold storage at $1^{\circ} \mathrm{C}$ and shelf life as compared to untreated fruits (Valero et al., 2005). Nonetheless, Dong et al.
(2002) found that, the application of 1-MCP not affected in colour changes of apricot. In addition, our results in the present study are in agreement with the outcome of Ali et al. (2013), Ezzat (2014) and Moradinezhad and Jahani (2016) they reported that, dipping apricots in SA treatments showed significant positive effect on the retention of colour than control fruits. Furthermore, these results are in line with the obtained by Fawbush et al. (2009) who reported that, treated 'Empire' apples with 1-MCP showed a significant higher in total phenolic content in the peel and flesh than untreated fruits during cold storage at $0.5^{\circ} \mathrm{C}$ for five months. Also, our results are in agreement with the previous studies of Ali et al. (2014) and Ezzat (2014) on apricots they realized that, fruit total phenolic content was significantly higher in treated fruit with SA than control fruit during cold storage and shelf life.

Effect of pre-storage applications of exposure to 1-methylcyclopropene (1-MCP), salicylic acid (SA) dipping and their combinations on superoxide dismutase (SOD), catalase (CAT), peroxidase (POX) and pectin methylesterase (PME) enzymes specific activities of 'Canino' apricot fruits during cold storage and shelf life

Changes in specific activities of antioxidant enzymes of SOD, CAT, POX and hydrolytic enzyme of PME in 'Canino' apricot fruits during cold storage period at $0^{\circ} \mathrm{C}$ shown in Tables 15,16 , 17 and 18. Pre-storage application with exposure 'Canino' apricot fruits to 0.5 or $1 \mathrm{ppm}$ of $1-\mathrm{MCP}$ or dipping in SA at 0.5 or $1 \mathrm{mM}$ concentration significantly increased the activities of SOD, CAT and POX enzymes during cold storage period as compared to untreated treatments (control). Contrary, these treatments were significantly decreased the activity of PME enzyme during cold storage period as compared to control treatments. In addition, the combination treatments were more effective in this aspect than individual treatments under this experiment.

Data also reveal that, exposure 'Canino' apricots to $0.5 \mathrm{ppm}$ of 1-MCP followed by dipping in SA at $1 \mathrm{mM}$ concentration showed a higher significant in activity of SOD (19.83 \& 20.96 units $\mathrm{mg}^{-1}$ protein), CAT (0.95 \& $0.96 \mu \mathrm{mol}$ $\mathrm{min}^{-1} \mathrm{mg}^{-1}$ protein) and POX (20.56 \& 20.45

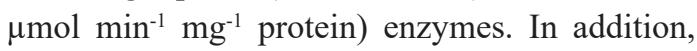
this application emerged a significant lower in activity of PME enzyme (24.92 \& $25.94 \mu \mathrm{mol}$ methyl ester $\mathrm{min}^{-1} \mathrm{mg}^{-1}$ protein) in the first and 
TABLE 15. Changes in specific activity of superoxide dismutase enzyme (units $\mathbf{m g}^{-1}$ protein) of 'Canino' apricots treated with exposure to 1-methylcyclopropene (1-MCP) application, salicylic acid (SA) dipping and their combined treatments during cold storage at $0^{\circ} \mathrm{C}$ for 28 days

\begin{tabular}{|c|c|c|c|c|c|c|c|c|c|c|}
\hline \multirow{3}{*}{ Pre-storage treatments } & \multicolumn{9}{|c|}{ Storage period (days) } & \multirow{3}{*}{ Means } \\
\hline & \multicolumn{2}{|c|}{$\mathbf{0}$} & \multirow{2}{*}{\multicolumn{2}{|c|}{7}} & \multirow{2}{*}{\multicolumn{2}{|c|}{$\begin{array}{c}14 \\
\text { Season } 201\end{array}$}} & \multirow{2}{*}{\multicolumn{2}{|c|}{21}} & \multirow[t]{2}{*}{28} & \\
\hline & & & & & & & & & & \\
\hline Distilled water (control) & 16.01 & no & 16.31 & mno & 16.88 & $\mathrm{klm}$ & 16.06 & no & 15.82 o & $16.22 \mathrm{G}$ \\
\hline $0.5 \mathrm{ppm} 1-\mathrm{MCP}$ & 16.01 & no & 16.64 & $\operatorname{lmn}$ & 17.35 & $\mathrm{jkl}$ & 17.85 & $\mathrm{ij}$ & $19.14 \mathrm{fgh}$ & $17.40 \mathrm{E}$ \\
\hline 1 ppm 1-MCP & 16.01 & no & 16.70 & $\operatorname{lmn}$ & 17.58 & $\mathrm{jk}$ & 18.47 & hi & $19.64 \mathrm{def}$ & $17.68 \mathrm{DE}$ \\
\hline $0.5 \mathrm{mM} \mathrm{SA}$ & 16.01 & no & 16.21 & mno & 16.90 & $\mathrm{klm}$ & 17.59 & $\mathrm{jk}$ & $18.48 \mathrm{hi}$ & $17.04 \mathrm{~F}$ \\
\hline $1 \mathrm{mM} \mathrm{SA}$ & 16.01 & no & 16.65 & $\operatorname{lmn}$ & 17.53 & $\mathrm{jk}$ & 18.43 & hi & $19.57 \mathrm{def}$ & $17.64 \mathrm{DE}$ \\
\hline $0.5 \mathrm{ppm} 1-\mathrm{MCP}+0.5 \mathrm{mM} \mathrm{SA}$ & 16.01 & no & 17.10 & $\mathrm{jkl}$ & 18.98 & fgh & 19.91 & de & $22.98 \mathrm{~b}$ & $19.00 \mathrm{~B}$ \\
\hline $0.5 \mathrm{ppm} 1-\mathrm{MCP}+1 \mathrm{mM} \mathrm{SA}$ & 16.01 & no & 17.51 & $\mathrm{jk}$ & 19.39 & efg & 21.00 & $\mathrm{c}$ & $25.22 \mathrm{a}$ & $19.83 \mathrm{~A}$ \\
\hline $1 \mathrm{ppm} 1-\mathrm{MCP}+0.5 \mathrm{mM} \mathrm{SA}$ & 16.01 & no & 16.92 & klm & 17.71 & $\mathrm{j}$ & 18.82 & gh & $20.21 \mathrm{~d}$ & $17.93 \mathrm{CD}$ \\
\hline 1 ppm 1-MCP + 1 mM SA & 16.01 & no & 16.72 & $\operatorname{lmn}$ & 17.78 & $\mathrm{ij}$ & 19.01 & fgh & $21.56 \mathrm{c}$ & $18.22 \mathrm{C}$ \\
\hline \multirow[t]{2}{*}{ Means } & 16.01 & $\mathrm{E}$ & 16.75 & $\mathrm{D}$ & 17.79 & $\mathrm{C}$ & 18.57 & $\mathrm{~B}$ & $20.29 \mathrm{~A}$ & \\
\hline & \multicolumn{9}{|c|}{ Season 2016} & \\
\hline Distilled water (control) & 16.21 & $\mathrm{u}$ & 16.78 & st & 17.19 & qrs & 16.37 & tu & $16.13 \mathrm{u}$ & $16.54 \mathrm{G}$ \\
\hline $0.5 \mathrm{ppm} 1-\mathrm{MCP}$ & 16.21 & $\mathrm{u}$ & 17.21 & qrs & 18.32 & o & 19.39 & $\operatorname{lmn}$ & 20.39 hij & $18.30 \mathrm{~F}$ \\
\hline $1 \mathrm{ppm} 1-\mathrm{MCP}$ & 16.21 & $\mathrm{u}$ & 17.48 & $q r$ & 18.49 & o & 19.83 & $\mathrm{jkl}$ & $21.77 \mathrm{ef}$ & $18.76 \mathrm{DE}$ \\
\hline $0.5 \mathrm{mM} \mathrm{SA}$ & 16.21 & $\mathrm{u}$ & 16.92 & rs & 18.11 & op & 19.19 & $\mathrm{mn}$ & $20.07 \mathrm{ijk}$ & $18.10 \mathrm{~F}$ \\
\hline $1 \mathrm{mM} \mathrm{SA}$ & 16.21 & $\mathrm{u}$ & 17.12 & qrs & 18.50 & o & 19.73 & $\mathrm{k} l \mathrm{~m}$ & $21.59 \mathrm{ef}$ & $18.63 \mathrm{E}$ \\
\hline $0.5 \mathrm{ppm} 1-\mathrm{MCP}+0.5 \mathrm{mM} \mathrm{SA}$ & 16.21 & $\mathrm{u}$ & 17.65 & $\mathrm{pq}$ & 19.86 & $\mathrm{jkl}$ & 21.34 & $\mathrm{fg}$ & $23.72 \mathrm{~b}$ & $19.75 \mathrm{~B}$ \\
\hline 0.5 ppm $1-\mathrm{MCP}+1 \mathrm{mM} \mathrm{SA}$ & 16.21 & $\mathrm{u}$ & 18.06 & op & 20.93 & $\mathrm{gh}$ & 22.99 & $\mathrm{c}$ & $26.63 \mathrm{a}$ & $20.96 \mathrm{~A}$ \\
\hline $1 \mathrm{ppm} 1-\mathrm{MCP}+0.5 \mathrm{mM} \mathrm{SA}$ & 16.21 & $\mathrm{u}$ & 17.27 & grs & 19.11 & $\mathrm{n}$ & 20.12 & $\mathrm{ijk}$ & $21.99 \mathrm{de}$ & $18.94 \mathrm{D}$ \\
\hline 1 ppm 1-MCP + 1 mM SA & 16.21 & $\mathrm{u}$ & 17.47 & $\mathrm{qr}$ & 19.32 & $\operatorname{lmn}$ & 20.57 & hi & $22.51 \mathrm{~cd}$ & $19.22 \mathrm{C}$ \\
\hline Means & 16.21 & $\mathrm{E}$ & 17.33 & $\mathrm{D}$ & 18.87 & $\mathrm{C}$ & 19.95 & $\mathrm{~B}$ & $21.64 \mathrm{~A}$ & \\
\hline
\end{tabular}

Means followed by the same letters within pre-storage treatments, storage periods and their interactions in each season are not significantly different at level $P \leq 0.05$ according to DMRT.

The duration of the exposure to 1-MCP and SA dipping were 24 hours and 5 minutes, respectively.

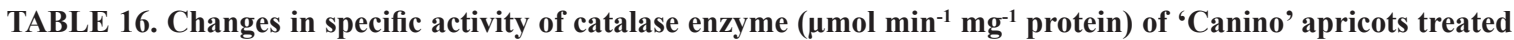
with exposure to 1-methylcyclopropene (1-MCP) application, salicylic acid (SA) dipping and their combined treatments during cold storage at $0^{\circ} \mathrm{C}$ for 28 days

\begin{tabular}{|c|c|c|c|c|c|c|c|c|c|}
\hline \multirow{3}{*}{ Pre-storage treatments } & \multicolumn{8}{|c|}{ Storage period (days) } & \multirow{3}{*}{ Means } \\
\hline & $\mathbf{0}$ & & 7 & 14 & & 21 & & 28 & \\
\hline & \multicolumn{8}{|c|}{ Season 2015} & \\
\hline Distilled water (control) & $0.78 \mathrm{~s}$ & 0.86 & $\mathrm{k}-\mathrm{n}$ & $0.89 \mathrm{~g}-\mathrm{j}$ & 0.86 & k-n & 0.84 & $\mathrm{~m}-\mathrm{q}$ & $0.84 \mathrm{~F}$ \\
\hline $0.5 \mathrm{ppm} 1-\mathrm{MCP}$ & $0.78 \mathrm{~s}$ & 0.83 & $\mathrm{o}-\mathrm{s}$ & $0.88 \mathrm{i}-1$ & 0.91 & $e-h$ & 0.89 & $f-j$ & $0.86 \mathrm{EF}$ \\
\hline 1 ppm 1-MCP & $0.78 \mathrm{~s}$ & 0.83 & $\mathrm{p}-\mathrm{s}$ & $0.87 \mathrm{j}-\mathrm{m}$ & 0.92 & $\mathrm{e}$ & 0.91 & efg & $0.86 \mathrm{DE}$ \\
\hline $0.5 \mathrm{mM}$ SA & $0.78 \mathrm{~s}$ & 0.84 & $n-r$ & $0.88 \mathrm{~h}-\mathrm{k}$ & 0.89 & $e-i$ & 0.89 & $g-j$ & $0.86 \mathrm{EF}$ \\
\hline $1 \mathrm{mM} \mathrm{SA}$ & $0.78 \mathrm{~s}$ & 0.83 & $\mathrm{p}-\mathrm{s}$ & $0.87 \mathrm{i}-\mathrm{m}$ & 0.92 & ef & 0.91 & $e-h$ & $0.86 \mathrm{DE}$ \\
\hline $0.5 \mathrm{ppm} 1-\mathrm{MCP}+0.5 \mathrm{mM} \mathrm{SA}$ & $0.78 \mathrm{~s}$ & 0.81 & rs & $0.85 \mathrm{k}-\mathrm{o}$ & 0.95 & e & 1.27 & $\mathrm{~b}$ & $0.93 \mathrm{~B}$ \\
\hline $0.5 \mathrm{ppm} 1-\mathrm{MCP}+1 \mathrm{mM} \mathrm{SA}$ & $0.78 \mathrm{~s}$ & 0.80 & $\mathrm{~s}$ & $0.841-p$ & 0.98 & $\mathrm{~d}$ & 1.34 & a & $0.95 \mathrm{~A}$ \\
\hline $1 \mathrm{ppm} 1-\mathrm{MCP}+0.5 \mathrm{mM} \mathrm{SA}$ & $0.78 \mathrm{~s}$ & 0.82 & qrs & $0.86 \mathrm{j}-\mathrm{n}$ & 0.93 & ef & 1.01 & $\mathrm{~d}$ & $0.88 \mathrm{D}$ \\
\hline $1 \mathrm{ppm} 1-\mathrm{MCP}+1 \mathrm{mM}$ SA & $0.78 \mathrm{~s}$ & 0.82 & qrs & $0.86 \mathrm{k}-\mathrm{n}$ & 0.95 & ef & 1.05 & $\mathrm{c}$ & $0.89 \mathrm{C}$ \\
\hline \multirow[t]{2}{*}{ Means } & $0.78 \mathrm{E}$ & 0.83 & $\mathrm{D}$ & $0.87 \mathrm{C}$ & 0.92 & $\mathrm{~B}$ & 1.01 & $\mathrm{~A}$ & \\
\hline & \multicolumn{8}{|c|}{ Season 2016} & \\
\hline Distilled water (control) & $0.76 \mathrm{q}$ & 0.84 & $j-p$ & $0.88 \mathrm{e}-\mathrm{k}$ & 0.85 & $\mathrm{j}-\mathrm{o}$ & 0.83 & $\mathrm{k}-\mathrm{q}$ & $0.83 \mathrm{E}$ \\
\hline 0.5 ppm 1-MCP & $0.76 \mathrm{q}$ & 0.80 & $\mathrm{~m}-\mathrm{q}$ & $0.87 \mathrm{f}-1$ & 0.90 & $e-i$ & 0.89 & $e-k$ & $0.85 \mathrm{DE}$ \\
\hline 1 ppm 1-MCP & $0.76 \mathrm{q}$ & 0.80 & $\mathrm{~m}-\mathrm{q}$ & $0.85 \mathrm{~h}-\mathrm{n}$ & 0.92 & ef & 0.91 & $e-h$ & $0.85 \mathrm{DE}$ \\
\hline $0.5 \mathrm{mM} \mathrm{SA}$ & $0.76 \mathrm{q}$ & 0.82 & $1-q$ & 0.87 e-1 & 0.90 & $e-j$ & 0.88 & e-k & $0.85 \mathrm{DE}$ \\
\hline $1 \mathrm{mM} \mathrm{SA}$ & $0.76 \mathrm{q}$ & 0.80 & $m-q$ & $0.86 \mathrm{~g}-\mathrm{m}$ & 0.92 & efg & 0.91 & $e-i$ & $0.85 \mathrm{DE}$ \\
\hline $0.5 \mathrm{ppm} 1-\mathrm{MCP}+0.5 \mathrm{mM} \mathrm{SA}$ & $0.76 \mathrm{q}$ & 0.78 & $\mathrm{pq}$ & 0.84 j-p & 0.93 & e & 1.25 & $\mathrm{~b}$ & $0.91 \mathrm{~B}$ \\
\hline $0.5 \mathrm{ppm} 1-\mathrm{MCP}+1 \mathrm{mM} \mathrm{SA}$ & $0.76 \mathrm{q}$ & 0.77 & $\mathrm{q}$ & $0.83 \mathrm{k}-\mathrm{p}$ & 1.02 & d & 1.40 & a & $0.96 \mathrm{~A}$ \\
\hline $1 \mathrm{ppm} 1-\mathrm{MCP}+0.5 \mathrm{mM} \mathrm{SA}$ & $0.76 \mathrm{q}$ & 0.79 & $n-q$ & $0.85 \mathrm{i}-\mathrm{o}$ & 0.92 & efg & 1.00 & $\mathrm{~d}$ & $0.87 \mathrm{CD}$ \\
\hline 1 ppm 1-MCP + 1 mM SA & $0.76 \mathrm{q}$ & 0.79 & opq & $0.84 \mathrm{j}-\mathrm{o}$ & 0.93 & ef & 1.10 & $\mathrm{c}$ & $0.88 \mathrm{C}$ \\
\hline Means & $0.76 \mathrm{E}$ & 0.80 & $\mathrm{D}$ & $0.86 \mathrm{C}$ & 0.92 & B & 1.02 & A & \\
\hline
\end{tabular}

Means followed by the same letters within pre-storage treatments, storage periods and their interactions in each season are not significantly different at level $P \leq 0.05$ according to DMRT.

The duration of the exposure to 1-MCP and SA dipping were 24 hours and 5 minutes, respectively.

Egypt. J. Hort. Vol. 45, No.1 (2018) 
TABLE 17. Changes in specific activity of peroxidase enzyme ( $\mu \mathrm{mol} \mathrm{min}^{-1} \mathrm{mg}^{-1}$ protein) enzyme of 'Canino' apricots treated with exposure to 1-methylcyclopropene (1-MCP) application, salicylic acid (SA) dipping and their combined treatments during cold storage at $0^{\circ} \mathrm{C}$ for 28 days

\begin{tabular}{|c|c|c|c|c|c|c|c|c|c|}
\hline \multirow{3}{*}{ Pre-storage treatments } & \multicolumn{8}{|c|}{ Storage period (days) } & \multirow{3}{*}{ Means } \\
\hline & & $\mathbf{0}$ & & 7 & 14 & & 21 & 28 & \\
\hline & \multicolumn{8}{|c|}{ Season 2015} & \\
\hline Distilled water (control) & 15.77 & $\mathrm{p}$ & 16.03 & $\mathrm{p}$ & $18.73 \mathrm{kl}$ & 17.02 & $\mathrm{~m}$ & $16.65 \mathrm{mn}$ & $16.84 \mathrm{~F}$ \\
\hline 0.5 ppm 1-MCP & 15.77 & $\mathrm{p}$ & 16.43 & no & $18.80 \mathrm{jkl}$ & 21.69 & $\mathrm{f}$ & $20.40 \mathrm{~h}$ & $18.62 \mathrm{D}$ \\
\hline $1 \mathrm{ppm} 1-\mathrm{MCP}$ & 15.77 & $\mathrm{p}$ & 16.53 & $\mathrm{n}$ & $18.91 \mathrm{jk}$ & 21.86 & ef & $20.58 \mathrm{~h}$ & $18.73 \mathrm{D}$ \\
\hline $0.5 \mathrm{mM}$ SA & 15.77 & $\mathrm{p}$ & 16.08 & op & 18.461 & 20.98 & g & $19.16 \mathrm{j}$ & $18.09 \mathrm{E}$ \\
\hline $1 \mathrm{mM} \mathrm{SA}$ & 15.77 & $\mathrm{p}$ & 16.47 & $\mathrm{n}$ & $18.84 \mathrm{jkl}$ & 21.80 & ef & $20.51 \mathrm{~h}$ & $18.68 \mathrm{D}$ \\
\hline $0.5 \mathrm{ppm} 1-\mathrm{MCP}+0.5 \mathrm{mM} \mathrm{SA}$ & 15.77 & $\mathrm{p}$ & 16.68 & $\mathrm{mn}$ & $19.91 \mathrm{i}$ & 23.35 & c & $24.50 \mathrm{~b}$ & $20.04 \mathrm{~B}$ \\
\hline 0.5 ppm 1-MCP + 1 mM SA & 15.77 & $\mathrm{p}$ & 16.73 & $\mathrm{mn}$ & $19.96 \mathrm{i}$ & 24.34 & $\mathrm{~b}$ & $26.02 \mathrm{a}$ & $20.56 \mathrm{~A}$ \\
\hline $1 \mathrm{ppm} \mathrm{1-MCP}+0.5 \mathrm{mM} \mathrm{SA}$ & 15.77 & $\mathrm{p}$ & 16.58 & $\mathrm{n}$ & $19.81 \mathrm{i}$ & 22.74 & $\mathrm{~d}$ & $22.05 \mathrm{ef}$ & $19.39 \mathrm{C}$ \\
\hline 1 ppm 1-MCP + 1 mM SA & 15.77 & $\mathrm{p}$ & 16.63 & $\mathrm{mn}$ & $19.86 \mathrm{i}$ & 22.95 & $\mathrm{~d}$ & $22.12 \mathrm{e}$ & $19.46 \mathrm{C}$ \\
\hline \multirow[t]{2}{*}{ Means } & 15.77 & $\mathrm{E}$ & 16.46 & $\mathrm{D}$ & $19.25 \mathrm{C}$ & 21.86 & A & $21.33 \mathrm{~B}$ & \\
\hline & \multicolumn{8}{|c|}{ Season 2016} & \\
\hline Distilled water (control) & 15.64 & $\mathrm{~m}$ & 16.19 & $\operatorname{lm}$ & $18.66 \mathrm{i}$ & 17.11 & $\mathrm{j}$ & $16.48 \mathrm{jkl}$ & $16.82 \mathrm{~F}$ \\
\hline 0.5 ppm 1-MCP & 15.64 & $\mathrm{~m}$ & 16.68 & $\mathrm{jkl}$ & $18.99 \mathrm{i}$ & 21.31 & $\mathrm{~d}$ & 20.06 efg & $18.54 \mathrm{D}$ \\
\hline 1 ppm 1-MCP & 15.64 & $\mathrm{~m}$ & 16.78 & $\mathrm{jkl}$ & $19.09 \mathrm{hi}$ & 21.43 & d & $20.61 \mathrm{e}^{6}$ & $18.71 \mathrm{D}$ \\
\hline $0.5 \mathrm{mM}$ SA & 15.64 & $\mathrm{~m}$ & 16.33 & $\mathrm{kl}$ & $18.64 \mathrm{i}$ & 20.55 & ef & $19.73 \mathrm{gh}$ & $18.18 \mathrm{E}$ \\
\hline $1 \mathrm{mM} \mathrm{SA}$ & 15.64 & $\mathrm{~m}$ & 16.72 & $\mathrm{jkl}$ & $19.02 \mathrm{i}$ & 21.36 & d & 20.55 ef & $18.66 \mathrm{D}$ \\
\hline $0.5 \mathrm{ppm} \mathrm{1-MCP}+0.5 \mathrm{mM} \mathrm{SA}$ & 15.64 & $\mathrm{~m}$ & 16.94 & $\mathrm{jkl}$ & $19.87 \mathrm{fg}$ & 22.92 & $\mathrm{c}$ & $24.36 \mathrm{~b}$ & $19.95 \mathrm{~B}$ \\
\hline 0.5 ppm 1-MCP + 1 mM SA & 15.64 & $\mathrm{~m}$ & 16.98 & $\mathrm{jk}$ & $19.92 \mathrm{efg}$ & 23.77 & $\mathrm{~b}$ & 25.94 a & $20.45 \mathrm{~A}$ \\
\hline $1 \mathrm{ppm} 1-\mathrm{MCP}+0.5 \mathrm{mM}$ SA & 15.64 & $\mathrm{~m}$ & 16.83 & jkl & $19.77 \mathrm{gh}$ & 22.65 & c & $22.43 \mathrm{c}$ & $19.46 \mathrm{C}$ \\
\hline 1 ppm 1-MCP + 1 mM SA & 15.64 & $\mathrm{~m}$ & 16.89 & $\mathrm{jkl}$ & $19.82 \mathrm{fg}$ & 22.85 & $\mathrm{c}$ & $22.50 \mathrm{c}$ & $19.54 \mathrm{C}$ \\
\hline Means & 15.64 & $\mathrm{D}$ & 16.70 & $\mathrm{C}$ & $19.31 \mathrm{~B}$ & 21.55 & A & $21.41 \mathrm{~A}$ & \\
\hline
\end{tabular}

Means followed by the same letters within pre-storage treatments, storage periods and their interactions in each season are not significantly different at level $P \leq 0.05$ according to DMRT.

The duration of the exposure to 1-MCP and SA dipping were 24 hours and 5 minutes, respectively.

TABLE 18. Changes in specific activity of pectin methylesterase enzyme ( $\mu \mathrm{mol}$ methyl ester $\mathrm{min}^{-1} \mathrm{mg}^{-1} \mathrm{protein}$ ) of 'Canino' apricots treated with exposure to 1-methylcyclopropene (1-MCP) application, salicylic acid (SA) dipping and their combined treatments during cold storage at $0^{\circ} \mathrm{C}$ for 28 days

\begin{tabular}{|c|c|c|c|c|c|c|c|c|c|}
\hline \multirow{3}{*}{ Pre-storage treatments } & \multicolumn{8}{|c|}{ Storage period (days) } & \multirow{3}{*}{ Means } \\
\hline & $\mathbf{0}$ & & 7 & 14 & 21 & 1 & & 28 & \\
\hline & \multicolumn{8}{|c|}{ Season 2015} & \\
\hline Distilled water (control) & $16.68 \mathrm{~m}$ & 21.80 & $\mathrm{jk}$ & $35.73 \mathrm{~g}$ & $74.15 \mathrm{~b}$ & & 121.97 & & $54.07 \mathrm{~A}$ \\
\hline $0.5 \mathrm{ppm} 1-\mathrm{MCP}$ & $16.68 \mathrm{~m}$ & 19.00 & & $22.95 \mathrm{jk}$ & $36.70 \mathrm{~g} g \mathrm{~g} g \mathrm{~g}$ & $\mathrm{~g}$ & 61.13 & $\mathrm{c}$ & $31.29 \mathrm{~B}$ \\
\hline 1 ppm 1-MCP & $16.68 \mathrm{~m}$ & 18.84 & & $22.78 \mathrm{jk}$ & $36.47 g$ & $\mathrm{~g}$ & 60.81 & $\mathrm{c}$ & $31.11 \mathrm{~B}$ \\
\hline $0.5 \mathrm{mM}$ SA & $16.68 \mathrm{~m}$ & 19.05 & 1 & $23.00 \mathrm{j}$ & $36.77 \mathrm{~g}$ & g & 61.22 & $\mathrm{c}$ & $31.34 \mathrm{~B}$ \\
\hline $1 \mathrm{mM} \mathrm{SA}$ & $16.68 \mathrm{~m}$ & 18.90 & 1 & $22.84 \mathrm{jk}$ & $36.56 g$ & $\mathrm{~g}$ & 60.93 & $\mathrm{c}$ & $31.18 \mathrm{~B}$ \\
\hline $0.5 \mathrm{ppm} 1-\mathrm{MCP}+0.5 \mathrm{mM} \mathrm{SA}$ & $16.68 \mathrm{~m}$ & 18.35 & 1 & $21.67 \mathrm{jk}$ & $27.57 \mathrm{~h}$ & hi & 44.90 & $\mathrm{e}$ & $25.83 \mathrm{D}$ \\
\hline 0.5 ppm 1-MCP + 1 mM SA & $16.68 \mathrm{~m}$ & 18.29 & 1 & $21.60 \mathrm{k}$ & $26.64 \mathrm{i}$ & & 41.40 & $\mathrm{f}$ & $24.92 \mathrm{E}$ \\
\hline $1 \mathrm{ppm} 1-\mathrm{MCP}+0.5 \mathrm{mM} \mathrm{SA}$ & $16.68 \mathrm{~m}$ & 18.53 & 1 & $22.00 \mathrm{jk}$ & $28.42 \mathrm{l}$ & $\mathrm{h}$ & 47.34 & $\mathrm{~d}$ & $26.60 \mathrm{C}$ \\
\hline 1 ppm 1-MCP + 1 mM SA & $16.68 \mathrm{~m}$ & 18.37 & 1 & $21.69 \mathrm{jk}$ & $28.01 \mathrm{l}$ & $\mathrm{h}$ & 46.98 & $\mathrm{~d}$ & $26.34 \mathrm{CD}$ \\
\hline \multirow[t]{2}{*}{ Means } & $16.68 \mathrm{E}$ & 19.01 & $\mathrm{D}$ & $23.81 \mathrm{C}$ & $36.81 \mathrm{H}$ & $\mathrm{B}$ & 60.74 & A & \\
\hline & \multicolumn{8}{|c|}{$\begin{array}{ll}23.81 \mathrm{C} & 56.81 \mathrm{~B} \\
\text { Season } 2016 & \end{array}$} & \\
\hline Distilled water (control) & $16.74 \mathrm{~m}$ & 22.94 & $\mathrm{k}$ & $37.13 \mathrm{~g}$ & $78.56 \mathrm{~b}$ & $\mathrm{~b}$ & 123.25 & $a$ & $55.72 \mathrm{~A}$ \\
\hline 0.5 ppm 1-MCP & $16.74 \mathrm{~m}$ & 19.13 & 1 & $24.95 \mathrm{j}$ & $38.11 q$ & g & 63.25 & $\mathrm{c}$ & $32.43 \mathrm{~B}$ \\
\hline 1 ppm 1-MCP & $16.74 \mathrm{~m}$ & 18.96 & 1 & $24.76 \mathrm{j}$ & $37.87 g$ & $\mathrm{~g}$ & 62.92 & $\mathrm{c}$ & $32.25 \mathrm{~B}$ \\
\hline $0.5 \mathrm{mM}$ SA & $16.74 \mathrm{~m}$ & 19.17 & 1 & $25.00 \mathrm{j}$ & $38.18 \mathrm{~g}$ & g & 63.34 & $\mathrm{c}$ & $32.48 \mathrm{~B}$ \\
\hline $1 \mathrm{mM} \mathrm{SA}$ & $16.74 \mathrm{~m}$ & 19.03 & 1 & $24.83 \mathrm{j}$ & $37.96 g$ & $\mathrm{~g}$ & 63.04 & $\mathrm{c}$ & $32.32 \mathrm{~B}$ \\
\hline $0.5 \mathrm{ppm} 1-\mathrm{MCP}+0.5 \mathrm{mM} \mathrm{SA}$ & $16.74 \mathrm{~m}$ & 18.82 & 1 & $22.53 \mathrm{k}$ & $29.78 \mathrm{~h}$ & $\mathrm{~h}$ & 46.08 & $\mathrm{e}$ & $26.79 \mathrm{D}$ \\
\hline 0.5 ppm 1-MCP + 1 mM SA & $16.74 \mathrm{~m}$ & 18.75 & 1 & $22.46 \mathrm{k}$ & $28.79 \mathrm{i}$ & i & 42.95 & $\mathrm{f}$ & $25.94 \mathrm{E}$ \\
\hline $1 \mathrm{ppm} 1-\mathrm{MCP}+0.5 \mathrm{mM} \mathrm{SA}$ & $16.74 \mathrm{~m}$ & 18.85 & 1 & $23.08 \mathrm{k}$ & $30.70 \mathrm{~h}$ & $\mathrm{~h}$ & 48.55 & $\mathrm{~d}$ & $27.58 \mathrm{C}$ \\
\hline $1 \mathrm{ppm} 1-\mathrm{MCP}+1 \mathrm{mM} \mathrm{SA}$ & $16.74 \mathrm{~m}$ & 18.84 & 1 & $22.55 \mathrm{k}$ & $30.25 \mathrm{r}$ & $\mathrm{h}$ & 47.91 & $\mathrm{~d}$ & $27.26 \mathrm{C}$ \\
\hline Means & $16.74 \mathrm{E}$ & 19.39 & $\mathrm{D}$ & $25.25 \mathrm{C}$ & $38.91 \mathrm{H}$ & B & 62.36 & A & \\
\hline
\end{tabular}

Means followed by the same letters within pre-storage treatments, storage periods and their interactions in each season are not significantly different at level $P \leq 0.05$ according to DMRT.

The duration of the exposure to 1-MCP and SA dipping were 24 hours and 5 minutes, respectively. 
second seasons, respectively under this study. In control fruits, the peak in activity of SOD, CAT and POX enzymes of 'Canino' apricots observed at 14 days of cold storage at $0^{\circ} \mathrm{C}$. Then, these activities began to show a slow downward trend till end of cold storage period and recorded the minimum activates of SOD $(16.22 \& 16.54$ units $\mathrm{mg}^{-1}$ protein), CAT (0.84 \& $0.83 \mu \mathrm{mol} \mathrm{\textrm {min } ^ { - 1 }}$ $\mathrm{mg}^{-1}$ protein) and POX (16.84 \& $16.82 \mu \mathrm{mol}$ $\mathrm{min}^{-1} \mathrm{mg}^{-1}$ protein) enzymes in 2015 and 2016 seasons, respectively. While, the peak in activities of these enzymes were recorded a week later by treated with either 1-MCP or SA alone (Tables 15, 16 and 17). In addition, treated 'Canino' apricot fruits with 1-MCP, SA and their combined treatments showed an increase in activity of SOD enzyme till end of cold storage at $0^{\circ} \mathrm{C}$ (Table 15). Furthermore, treated apricots with exposure to 0.5 ppm of 1-MCP for 24 hours then dipped in either $0.5 \mathrm{mM}$ or $1 \mathrm{mM}$ concentration of SA for $5 \mathrm{~min}$ showed a gradual increase in activities of CAT and POX enzyme till end of cold storage period at $0^{\circ} \mathrm{C}$ in the two seasons under this experiment (Tables 16 and 17).

Concerning the effect of storage period, with the extension of the storage period at $0^{\circ} \mathrm{C}$, there were an upward trend in activities of SOD, CAT

TABLE 19. Changes in specific activities of superoxide dismutase (SOD), catalase (CAT), peroxidase (POX) and pectin methylesterase (PME) enzymes of 'Canino' apricots treated with exposure to 1-methylcyclopropene (1MCP) application, salicylic acid (SA) dipping and their combined treatments after cold storage at $0^{\circ} \mathrm{C}$ for 28 days and then transferred to about $25^{\circ} \mathrm{C}$ for 3 days shelf life

\begin{tabular}{|c|c|c|c|c|c|c|c|c|}
\hline \multirow[t]{2}{*}{ Pre-storage treatments } & \multicolumn{2}{|c|}{$\begin{array}{c}\text { SOD } \\
\text { (units } \mathrm{mg}^{-1} \text { protein) }\end{array}$} & \multicolumn{2}{|c|}{ 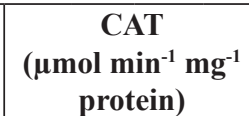 } & \multicolumn{2}{|c|}{$\begin{array}{c}\text { POX } \\
\left(\mu \mathrm{mol} \mathrm{min}^{-1} \mathrm{mg}^{-1}\right. \\
\text { protein })\end{array}$} & \multicolumn{2}{|c|}{$\begin{array}{l}\text { PME ( } \mu \text { mol methyl } \\
\text { ester } \text { min }^{-1} \text { mg-1 }^{-1} \\
\text { protein) }\end{array}$} \\
\hline & $\begin{array}{c}\text { Season } \\
2015\end{array}$ & $\begin{array}{c}\text { Season } \\
2016\end{array}$ & $\begin{array}{c}\text { Season } \\
2015\end{array}$ & $\begin{array}{c}\text { Season } \\
2016\end{array}$ & $\begin{array}{c}\text { Season } \\
2015\end{array}$ & $\begin{array}{c}\text { Season } \\
2016\end{array}$ & $\begin{array}{c}\text { Season } \\
2015\end{array}$ & $\begin{array}{c}\text { Season } \\
2016\end{array}$ \\
\hline Distilled water (control) & $15.57 \mathrm{e}$ & $15.88 \mathrm{f}$ & $0.81 \mathrm{f}$ & $0.80 \mathrm{~g}$ & $15.83 \mathrm{f}$ & $15.70 \mathrm{f}$ & $179.47 \mathrm{a}$ & $184.34 \mathrm{a}$ \\
\hline 0.5 ppm 1-MCP & $22.02 \mathrm{~cd}$ & $22.85 \mathrm{~cd}$ & $0.88 \mathrm{e}$ & $0.88 \mathrm{ef}$ & $18.31 \mathrm{~d}$ & $18.60 \mathrm{~d}$ & $102.81 \mathrm{c}$ & $105.37 \mathrm{bc}$ \\
\hline 1 ppm 1-MCP & $22.39 \mathrm{c}$ & $23.50 \mathrm{c}$ & $0.90 \mathrm{e}$ & $0.90 \mathrm{e}$ & $18.49 \mathrm{~d}$ & $18.77 \mathrm{~d}$ & $101.42 \mathrm{c}$ & $103.47 \mathrm{c}$ \\
\hline $0.5 \mathrm{mM}$ SA & $21.66 \mathrm{~cd}$ & $21.39 \mathrm{e}$ & $0.86 \mathrm{ef}$ & $0.86 \mathrm{f}$ & $17.60 \mathrm{e}$ & $17.88 \mathrm{e}$ & $105.25 \mathrm{~b}$ & $107.48 \mathrm{~b}$ \\
\hline $1 \mathrm{mM} \mathrm{SA}$ & $22.38 \mathrm{c}$ & $23.43 \mathrm{c}$ & $0.89 \mathrm{e}$ & $0.90 \mathrm{e}$ & $18.42 \mathrm{~d}$ & $18.70 \mathrm{~d}$ & $101.90 \mathrm{c}$ & $103.79 \mathrm{c}$ \\
\hline $0.5 \mathrm{ppm} 1-\mathrm{MCP}+0.5 \mathrm{mM} \mathrm{SA}$ & $24.15 \mathrm{~b}$ & $25.29 \mathrm{~b}$ & $1.21 \mathrm{~b}$ & $1.19 \mathrm{~b}$ & $25.00 \mathrm{~b}$ & $24.02 \mathrm{~b}$ & $66.22 \mathrm{e}$ & $67.39 \mathrm{e}$ \\
\hline 0.5 ppm 1-MCP + 1 mM SA & $27.48 \mathrm{a}$ & $28.80 \mathrm{a}$ & $1.32 \mathrm{a}$ & $1.38 \mathrm{a}$ & $27.54 \mathrm{a}$ & $27.03 \mathrm{a}$ & 58.69 & 59.67 \\
\hline $1 \mathrm{ppm} 1-\mathrm{MCP}+0.5 \mathrm{mM} \mathrm{SA}$ & $21.50 \mathrm{~d}$ & $22.12 \mathrm{de}$ & $0.96 \mathrm{~d}$ & $0.96 \mathrm{~d}$ & $21.50 \mathrm{c}$ & $21.68 \mathrm{c}$ & 73.60 & 76.83 \\
\hline 1 ppm 1-MCP + 1 mM SA & $22.46 \mathrm{c}$ & $23.75 \mathrm{c}$ & $1.05 \mathrm{c}$ & $1.07 \mathrm{c}$ & $21.57 \mathrm{c}$ & $21.75 \mathrm{c}$ & $72.97 \mathrm{~d}$ & $75.39 \mathrm{~d}$ \\
\hline
\end{tabular}

Means followed by the same letters in each column for every season are not significantly different according to DMRT at level $P \leq 0.05$. The duration of the exposure to 1-MCP and SA dipping were 24 hours and 5 minutes, respectively.

and PME enzymes of 'Canino' apricots (Tables 15, 16 and 18). Data also revealed that, the highest activities of SOD (20.29 \& 21.64 units

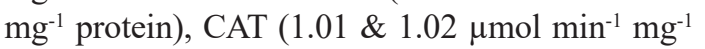
protein) and PME (60.74 \& $62.36 \mu \mathrm{mol}$ methyl ester $\mathrm{min}^{-1} \mathrm{mg}^{-1}$ protein) enzymes were recorded after 28 days of cold storage at $0^{\circ} \mathrm{C}$ in the first and second seasons, respectively. On contrary, the activity of POX enzymes showed an upward trend through the cold storage up to 21 days of cold storage $\left(21.86 \& 21.55 \mu \mathrm{mol} \mathrm{min} \mathrm{mg}^{-1}\right.$ protein) then the activity started decreasing till end of cold storage period $(21.33 \& 21.41 \mu \mathrm{mol}$ $\mathrm{min}^{-1} \mathrm{mg}^{-1}$ protein) in the two seasons, respectively (Table 17). Regarding to the interaction effect, significant differences were found between prestorage treatments and storage periods at $p \leq 0.05$ for specific activities of SOD, CAT, POX and PME enzymes in both seasons in this study.

Statistical data in Table 19 emerge that, all prestorage treatments of 'Canino' apricots showed significant increment in activities of antioxidant enzymes of SOD, CAT and POX in comparison with those untreated fruits (control) after 28 days at $0^{\circ} \mathrm{C}$ plus 3 days shelf life at ambient temperature $\sim 25^{\circ} \mathrm{C}$. On contrary, these treatments had a significant decrease in PME activity as compared to control fruits after 28 days at $0^{\circ} \mathrm{C}$ plus 3 days shelf life. Moreover, these data also cleared that, the combination treatment of exposure 'Canino' apricots to $0.5 \mathrm{ppm}$ of $1-\mathrm{MCP}$ then its dipping in $1 \mathrm{mM}$ concentration of SA was more effective in this aspect. However, after end of cold storage (28 days) and during shelf life at ambient temperature 
a gradual increase in the activity of SOD enzyme was noticed in all treated apricots than untreated fruits (control) in both seasons. In addition, decreasing trend was observed in activity of POX enzyme in pre-storage treatment including control otherwise, apricots treated with exposure to $0.5 \mathrm{ppm}$ of $1-\mathrm{MCP}$ then its dipping in $1 \mathrm{mM} \mathrm{SA}$ concentration that was appeared a gradual increase in activity of POX enzyme during shelf life at ambient temperature. Moreover, declined trend in all treatment including control were noticed in the activities of CAT and PME enzymes after 28 days at $0^{\circ} \mathrm{C}$ plus 3 days shelf life at ambient temperature.

1-MCP and SA induce the activities of defense enzymes and improvement the storability of apricots by reducing the stress of cold storage or maintenance the membrane rigidity ( $\mathrm{Li}$ et al., 2007 and Ezzat, 2014). In this context, 1-MCP and SA treatments are effective for inhibition of ethylene production thus, delayed ripening process and fruits senescence by reducing the degradation enzymes as documented by Fan et al. (2000), Srivastava and Dwivedi (2000), Dong et al. (2002) and Özkaya et al. (2016).

Reactive oxygen species could be lead to membrane lipid peroxidation and causing severe injury to the cell membrane resulting in fruits senescence (Karuppanapandian et al., 2011). There were many protective enzymes that eliminated active oxygen in plant tissues such as SOD, POX and CAT which play a significant preventive role against oxidative damages caused by reactive oxygen species and provides cellular resistance against the toxicity of $\mathrm{H} 2 \mathrm{O} 2$ (Sharma et al., 2012). Superoxide radicals are converting into $\mathrm{H} 2 \mathrm{O} 2$ in result of SOD activity enzyme and the same is disintegrating into water and oxygen by activities of CAT and POX enzymes (Mittler, 2002). There was a close relationship between activities of antioxidant enzymes and ripening process as well as fruits senescence (Akhtar, 2009 and Tareen et al., 2012b).

In the present experiment, the higher activities of antioxidant enzymes of SOD, CAT and POX that induced by treated 'Canino' apricots with espouser to 1-MCP and SA dipping especially combined treatments might be attributed to the lowered activity of lipoxygenase that is partly responsible for superoxide radicals formation (Blokhina et al., 2003). In addition, delayed ripening and senescence processes by enhancing the activities of antioxidant enzymes that eliminated active oxygen species during storage
(Akhtar, 2009 and Tareen et al., 2012b). The decreasing activities of SOD, CAT and POX enzymes in control treatment of 'Canino' apricots suggests weakened capability of cell to scavenge superoxide radicals, so untreated apricot fruits were deterioration quickly during storage and shelf life.

PME enzyme catalyzing hydrolysation of methyl ester group of pectin, is constitutes a key control enzyme for both assembly and disassembly of pectin networks by determining tissue integrity during fruit senescence by regulating cation binding to cell wall (Vicente et al. 2007 and Payasi et al., 2009).

Our proposal is consistent with the results of Egea et al. (2010) and Shi et al. (2013) in this respect, whereby they reported that, $1-\mathrm{MCP}$ treatment was significantly contributed in increase activities of SOD, CAT and POX enzymes of apricots as compared to untreated fruits (control) during storage. Similar results also reported by Fawbush et al. (2009) on apples. In addition, our results are in agreement with the outcome of Wang et al. (2006) and Tareen et al. (2012b) on peaches, Valero et al. (2011) on sweet cherries and Ali et al. (2014) and Ezzat (2014) on apricots they demonstrated that, treated fruits with SA have shown a significant continuous increase in antioxidant activity during storage than control fruits. Moreover, SA dipping treatments have showed an increase in activity of POX enzyme during storage of apples (Mo et al., 2008) and oranges (Mohamed et al., 2016a).

Previously documented research work have also showed similar results that papaya fruits treated with exposure to $90 \mathrm{ppb}$ of $1-\mathrm{MCP}$ exhibited decreased activity of PME enzyme than control fruits (Ahmad et al., 2013). Moreover, these results are in similarity with the findings of Özkaya et al. (2016) on nectarines. In addition, our proposal is consistent with the results of Srivastava and Dwivedi (2000) in this respect, whereby they reported that, SA treatment reduced the activities of cell wall degrading enzymes of banana fruits.

Therefore, our results in this research unequivocally indicated that, the application of exposure 'Canino' apricots to $0.5 \mathrm{ppm} 1-\mathrm{MCP}$ for 24 hours and then dipping in either 0.5 or $1 \mathrm{mM}$ $\mathrm{SA}$ for $5 \mathrm{~min}$ could be stimulated the activities of SOD, CAT and POX as documented by Shi et al. (2013) and Ezzat (2014). In addition, these 
applications could be reduced the activity of PME and de-esterification of pectin as mentioned by Mohamed et al. (2016a) and Özkaya et al. (2016), thus these treatments maintained fruit firmness by delaying ripening and senescence processes of apricot fruits than untreated fruits (control) throughout the cold storage and shelf life.

\section{Conclusion}

In general, this experiment showed the effectiveness of pre-storage treatments of 'Canino' apricots with exposure to either 0.5 or $1 \mathrm{ppm}$ of 1-MCP for 24 hours at room temperature, SA dipping in either 0.5 or $1 \mathrm{mM}$ concentration for 5 min and their combined treatments on keeping qualities, enhancing activities of antioxidant enzymes and reducing activity of PME enzyme. Pre-storage application of 'Canino' apricots with exposure to either 0.5 or $1 \mathrm{ppm}$ of $1-\mathrm{MCP}$ then its dipping in either 0.5 or $1 \mathrm{mM}$ concentration of SA was more effective in maintaining physical and chemical characteristics. In addition, delaying colour development, increasing total phenolic content and enhancing the activities of antioxidant enzyme of SOD, CAT and POX with reducing the activity of PME enzyme than each treatment alone or control during cold storage at $0^{\circ} \mathrm{C}$ for 28 days as well as end of cold storage ( 28 days) plus 3 days shelf life at ambient temperature. Therefore, pre-storage application of 'Canino' apricots with exposure to 1-MCP at $0.5 \mathrm{ppm}$ for 24 hours then its dipping in either 0.5 or $1 \mathrm{mM}$ concentration of SA consider that is a reliable treatments and promising methods to delaying ripening process and fruit senescence during cold storage and shelf life.

Author contributions: A.F. Abd El-khalek conceived of and designed the experiment. A.F. Abd El-khalek and M.I. Mohamed purchased reagents, materials and analysis tools as well as performed the experiment. A.F. Abd El-khalek analyzed the data and drafted the manuscript. U.K. El-Abbasy revised the manuscript.

Funding statements: the authors declare that there is no received external funding for this study.

Conflicts of interest: the authors declare that there are no conflicts of interest related to the publication of this study.

\section{References}

Ahmad, A., Ali, Z.M. and Zainal, Z. (2013) Effect of 1-Methylcyclopropene (1-MCP) treatment on firmness and softening related enzymes of 'Sekaki' papaya fruit during ripening at ambient. Sains Malaysiana, 42 (7), 903-909.
Akhtar, A. (2009) Relationship of antioxidants with qualitative changes in local cultivars of loquat (Eriobotrya japonica Lindl.) fruit during storage. Ph.D Thesis. Rawalpindi, Arid Agriculture University.

Ali, S., Masud, T., Abbasi, K. S., Mahmood, T. and Ali, A. (2013) Effect of different concentrations of salicylic acid on keeping quality of apricot cv. Habi at ambient storage. Journal of Biological and Food Science Research, 2 (6), 69-78.

Ali, S., Masud, T., Abbasi, K. S., Ahmad, A., Mahmood, T. and Ali, A. (2014) Biochemical attributes of apricot as influenced by salicylic acid during ambient storage. International Journal of Biosciences, 4 (10), 176-187.

Anonymous, (2014) Ministry of agriculture and land reclamation, economic affairs sector, bulletin of the agricultural statistics.

AOAC, (2000) Official Methods of Analysis, $17^{\text {th }}$ ed., Association of Official Analytical Chemist, Washington, D.C, 16-20.

Asghari, M. and Aghdam, M.S. (2010) Impact of salicylic acid on postharvest physiology of horticultural crops. Trends in Food Science and Technology, 21, 502-509.

Blankenship, S.M. and Dole, J.M. (2003) 1-Methylcyclopropene: a review. Postharvest. Biology and Technology, 28, 1-25.

Blokhina, O., Virolainen, E. and Fagerstedt, K.V. (2003) Antioxidants, oxidative damage and oxygen deprivation stress: a review. Annals of Botany, 91, 179-194.

Botondi R., Massantini, R., Crisa, A. and Mencarelli, F. (1999) Effect of low oxygen for $9 \mathrm{D}$ at 5 and $18^{\circ} \mathrm{C}$ on postharvest quality of ripe apricots. Italian Journal of Food Science, 11 (3), 207-220.

Bradford, M.M. (1976) A rapid and sensitive method for quantitation of microgram quantities of protein utilizing the principle of protein-dye binding. Analytical Biochemistry, 72, 248-254.

Cheng, Y., Dong, Y., Yan, H., Ge, W., Shen, C., Guan, J., Liu, L. and Zhang, Y. (2012) Effects of 1-MCP on chlorophyll degradation pathway-associated genes expression and chloroplast ultrastructure during the peel yellowing of Chinese pear fruits in storage. Food Chemistry, 135 (2), 415-422.

Clairbone, A. (1985) Catalase activity. In: Greenwald, R. (Edition), Handbook of methods for oxygen radical research. CRC Press, Boca Raton, FL, 283284.

De Martino, G., Massantini, R., Botondi, R. and Mencarelli, F. (2002) Temperature affects impact injury on apricot fruit. Postharvest Biology and Technology, 25 (2), 145-149.

De Rigal, D., Gauillard, F. and Richard-Forget, F. (2000) Changes in the carotenoid content of 
apricot (Prunus armeniaca, var Bergeron) during enzymatic browning: $\beta$-carotene inhibition of chlorogenic acid degradation. Journal of the Science of Food and Agriculture, 80, 763-768.

Dong, L., Lurie, S. and Zhou, H. (2002) Effect of 1 -methylcyclopropene on ripening of 'Canino' apricots and 'Royal Zee' plums. Postharvest Biology and Technology, 24, 135-145.

Dragovic-Uzelac, V., Levaj, B., Mrkic, V., Bursac, D. and Boras, M. (2007) The content of polyphenols and carotenoids in three apricot cultivars depending on stage of maturity and geographical region. Food Chemistry, 102 (3), 966-975.

Egea, I., Flores, F.B., Martinez-Madrid, M.C., Romojaroa, F. and Sánchez-Bela, P. (2010) 1-Methylcyclopropene affects the antioxidant system of apricots (Prunus armeniaca L. cv. B'ulida) during storage at low temperature. Journal of the Science of Food and Agriculture, 90, 549-555.

Erkan, M. and Eski. H. (2012) Combined treatment of modified atmosphere packaging and 1-methylcyclopropene improves postharvest quality of Japanese plums. Turk Journal Agriculture, 36, 563-575.

Ezzat, A. (2014) Pomological evaluation of apricot cultivars and the roles of postharvest application of salicylic acid and methyl jasmonate on stress resistance. Ph.D Thesis. University of Deprecen, Hungry.

Ezzat. A., Nyéki, J., Soltész, M., Amriskó, L., Balázs, G., Mikita, T. and Szabó, Z. (2012) Storability of some apricot varieties as affected by storage period. International Journal of Horticultural Science, 18 (1), 339-342.

Fan, X., Argenta, L. and Mattheis, J.P. (2000) Inhibition of ethylene action by 1-methylcyclopropene prolongs storage life of apricots. Postharvest Biology and Technology, 20, 135-142.

Fawbush, F., Nock, J. and Watkins, C. (2009)Antioxidant contents and activity of 1-methylcyclopropene (1-MCP)-treated 'Empire' apples in air and controlled atmosphere storage. Postharvest Biology and Technology, 52, 30-37.

Femenia, A., Garcia-Conesab, M., Sirnal, S. and Rossello C. (1998) Characterisation of the cell walls of loquat (Eriobotrya japonica L.) fruit tissues. Carbohydrate Polymers, 35, 169-171.

Giannopolities, C.N. and Ries, S.K. (1977) Superoxide dismutase: Occurrence in higher plants. Plant Physiology, 59, 315-318.

Hagerman, A.E. and Austin, P.J. (1986) Continuous spectrophotometric assay for plant pectin methyl esterase. Journal of Agricultural and Food Chemistry, 34, 440-444.

Hajilou, J. and Fakhimrezaei, S. (2013) Effects of postharvest calcium chloride or salicylic acid treatments on the shelf-life and quality of apricot fruit. Journal of Horticultural Science and Biotechnology, 88 (5), 600-604.

Herzog, V. and Fahimi, H. (1973) Determination of the activity of peroxidase. Analytical Biochemistry, 55, 554-562.

Jan, I. and Rab., A. (2012) Influence of storage duration on physico-chemical changes in fruit of apple cultivars. Journal of Animal and Plant Science, 22 (3), 708-714.

Jin, P., Shang, H., Chen, J., Zhu, H., Zhao, Y. and Zheng, Y. (2011) Effect of 1-methylcyclopropene on chilling injury and quality of peach fruit during cold storage. Journal of Food Science, 76, 485-491.

Karuppanapandian, T., Moon, J., Kim, C., Manoharan, K. and Kim, W. (2011) Reactive oxygen species in plants: their generation, signal transduction, and scavenging mechanisms. Australian Journal of Crop Science, 5, 709-725.

Kays, S.J. (1991) Postharvest physiology of perishable plant products. AVI, Van Nostrand Reinhold, New York, USA $532 \mathrm{p}$.

Li, Z., Wang, L., Wang, W. and Zhu, Y. (2007) Physiological effect and application of 1-MCP on delaying fruit senescence. Plant Physiology, 43, 201-206.

Liu, H.X., Jiang, W.B., Zhou, L.G., Wang, B.G. and Luo, Y.B. (2005) The effects of 1-methylcyclopropene on peach fruit (Prunus persica L. cv. Jiubao) ripening and disease resistance. International Journal of Food Science and Technology, 40 (1), 1-7.

Macheix, J.J., Fleuriet, A. and Billot, J. (1990) Importance and roles of phenolic compounds in fruits. In: fruit phenolics. CRC Press, Boca Raton, Florida, USA, 239-278.

Mapson, C.W. (1970) Vitamins in fruits: stability of L-ascorbic acid. In: biochemistry of fruits and their products. Academic Press, London, 376-387.

Masia, A. (1998) Superoxide dismutase and catalase activities in apple fruit during ripening and postharvest and with special reference to ethylene. Physiologia Plantarum, 104 (4), 668-672.

Mita, S., Kirita, C., Kato, M., Hyodo, H. (1999) Expression of ACC synthase is enhanced earlier than that of ACC oxidase during fruit ripening of mume (Prunus mume). Physiologia Plantarum, 107, 319-328.

Mittler, R. (2002) Oxidative stress antioxidants and stress tolerance. Trends in Plant Science, 7 (9), 405-410.

Mo, Y., Gong, D., Liang, G., Han, R., Xie, J. and Li, W. (2008) Enhanced preservation effects of sugar apple fruits by salicylic acid treatment during postharvest storage. Journal of the Science of Food and Agriculture, 88, 2693-2699. 
Mohamed, M.A.A.,Abd El-khalek, A.F., and Abdelaziz, A.M.R.A. (2016b) Increasing storability of mango cv. 'Zibda' fruits by 1-methylcyclopropene and gibberellic acid postharvest applications. Egyptian Journal of Horticulture, 43 (2), 277-298.

Mohamed, M.A.A., Abd El-khalek, A.F., Elmehrat, H.G and Gehan Mahmoud, A. (2016a) Pre-storage application of antioxidant alleviates chilling injury and maintains quality of Valencia orange fruits stored at low temperature. Egyptian Journal of Horticulture, 43 (1), 175-193.

Moradinezhad, F. and Jahani, M. (2016) Quality improvement and shelf life extension of fresh apricot fruit (Prunus Armeniaca cv. Shahroudi) using postharvest chemical treatments and packaging during cold storage. International Journal of Horticultural Science and Technology, 3 (1), 9-18.

M-STAT, (1993) A microcomputer program for the design, arrangement and analysis of agronomic research experiments. Michigan State University.

Özkaya, O., Yildirimb, D., Dündara, Ö. and Seyhan Tükel, S. (2016) Effects of 1-methylcyclopropene (1-MCP) and modified atmosphere packaging on postharvest storage quality of nectarine fruit. Scientia Horticulturae, 198, 454-461.

Payasi, A., Mishra, N.N., Chaves, A.L.S. and Singh, R. (2009) Biochemistry of fruit softening: an overview. Physiology and Molecular Biology of Plants, 15, 103-113.

Prusky, D. and Keen, N.T. (1993) Involvement of preformed antifungal compounds and the resistance of subtropical fruits to fungal decay. Plant Disease, 77, 114-119.

Raskin, I. (1992) Salicylate, a new plant hormone. Plant Physiology, 99, 799-803.

Sharma P., Jha, AB., Dubey, R.S. and Pessarakli, M. (2012) Reactive oxygen species, oxidative damage, and antioxidative defense mechanism in plants under stressful conditions. Journal of Experimental Botany, 1-26.

Shi, T., Li, Z., Zhang, Z., Zhang, C. and Gao, Z. (2013) Effect of 1-methylcyclopropene (1- MCP) treatment on antioxidant enzymes of postharvest Japanese apricot. African Journal of Biotechnology, 12 (7), 689-694.

Sisler, E.C. (2006) The discovery and development of compounds counteracting ethylene at the receptor level. Biotechnology Advances, 24, 357-367.

Sisler, E.C. and Serek, M. (1997) Inhibitors of ethylene responses in plants at the receptor level: recent developments. Physiologia Plantarum, 100, 577582.

Slinkard, K. and Singleton, V.L. (1977) Total phenol analysis: automation and comparison with manual methods. American Journal of Enology and Viticulture, 28, 49-55.

Egypt. J. Hort. Vol. 45, No.1 (2018)
Solis-Solis, H.M., Calderon-Santoyo, M., GutierrezMartinez, P., Schorr-Galindo, S. and RagazzoSanchez, J.A. (2007) Discrimination of eight varieties of apricot (Prunus armeniaca) by electronic nose, LLE and SPME using GC/MS and multivariate analysis. Sensors and Actuators, B: Chemical, 125, 415-421.

Srivastava, M.K. and Dwivedi, U.N. (2000) Delayed ripening of banana fruit by salicylic acid. Plant Sciences, 158, 87-96.

Stanley, J., Marshall, R., Ogwaro, J., Feng, R., Wohlers, M. and Woolf, A. (2010) Postharvest storage temperatures impact significantly on apricot fruit quality. Acta Horticulturae, 880, 525-532.

Tareen, M.J., Abbasi, N.A. and Hafiz, I.A. (2012a) Effect of salicylic acid treatments of storage life of peach fruits cv. 'Flordaking'. Pakistan Journal of Botany, 44 (1), 119-124.

Tareen, M.J., Abbasi, N.A. and Hafiz, I.A. (2012b) Postharvest application of salicylic acid enhanced antioxidant enzyme activity and maintained quality of peach cv. 'Flordaking' fruit during storage. Scientia Horticulturae, 142, 221-228.

Valero, D., Guillén, F., Valverde, J.M., MartínezRomero, D., Castillo, S. and Serrano, M. (2005) 1-MCP use in Prunus spp. to maintain fruit quality and extend shelf life during storage: a comparative study. Acta Horticulturae, 682, 933-940.

Valero, D., Diaz-Mula, H.M., Zapata, P.J., Castillo, S., Guillén, F., Martinez-Romero, D., Serrano, M. (2011) Postharvest treatments with salicylic acid, acetylsalicylic acid or oxalic acid delayed ripening and enhanced bioactive compounds and antioxidant capacity in sweet cherry. Journal of Agricultural and Food Chemistry, 59, 5483-5489.

Vicente, A.R., Saladie, M., Rose, J.K.C. and Labavitch, J.M. (2007) The linkage between cell wall metabolism and fruit softening: looking to the future. Journal of the Science of Food and Agriculture, 87, 1435-1448.

Wang, L., Chen, S., Kong, W., Li, S. and Archbold, D.D. (2006) Salicylic acid pretreatment alleviates chilling injury and affects the antioxidant system and heat shock proteins of peaches during cold storage. Postharvest Biology and Technology, 41, 244-251.

Watkins, C. and Harman, J. (1981) Use of penetrometer to measure flesh firmness of fruit. Orchadist, N.Z., 14-16.

Wettestein, D. (1957) Chlorophyll lethal and the submicroscopic form change of plastids. Experimental Cell Research, 12, 427-434.

Wills, R.H., McGlasson, B., Graham, D. and Joyce, D. (1998) Postharvest: an Introduction to the physiology and handling of fruit, vegetables and ornamentals, $4^{\text {th }}$ Edition. CAP International, Wallingford Oxen 108DE, UK., 4, 262 p. 


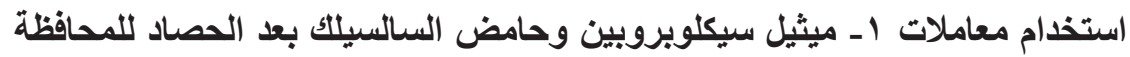
الجودة وتحسين نشاط مضادات الأكسدة الإنزيمية لثمار المشمش صنئ صنف 'كاتينو، أثناء التخزين المبرد

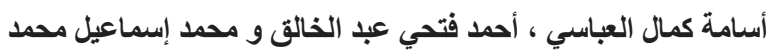

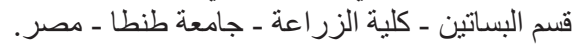

\begin{abstract}
تعتبر ثمار المشمش أحد الثمار الكلايمكترية التي تنضج بسر عة بعد الحصاد و التي تؤدي بالتالي لتدهور هاوقصر

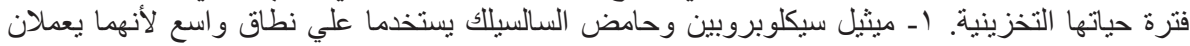

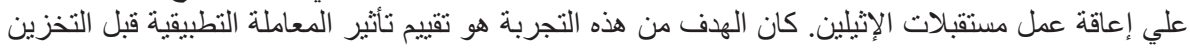

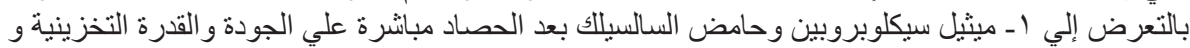

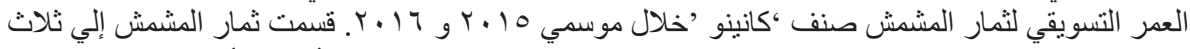

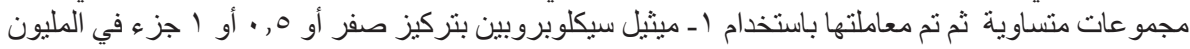

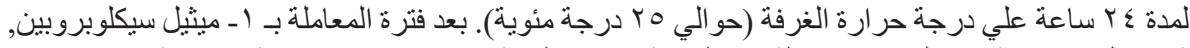

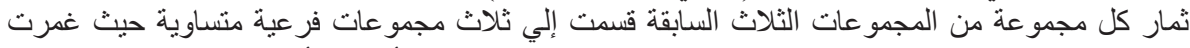

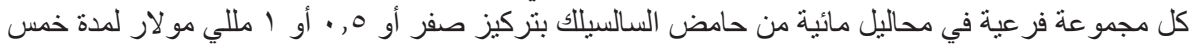

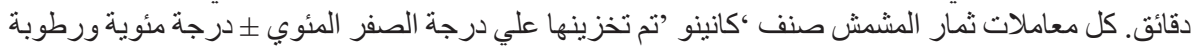

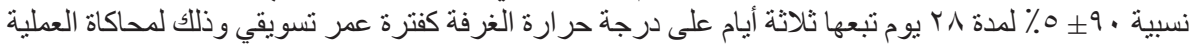

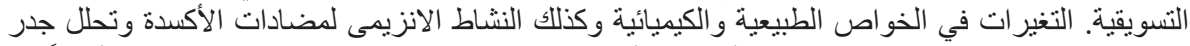

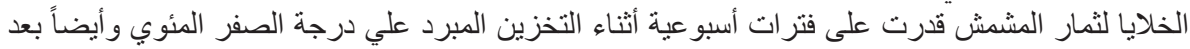

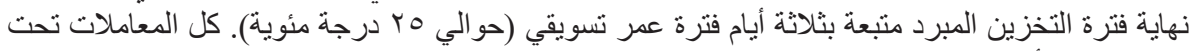

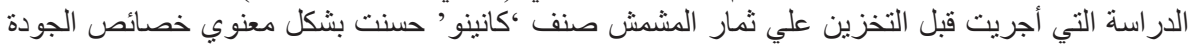

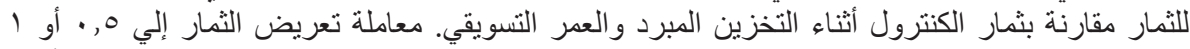

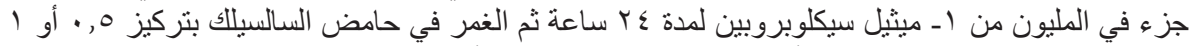

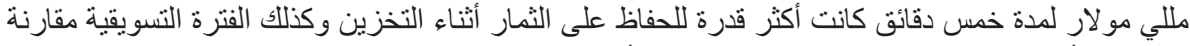

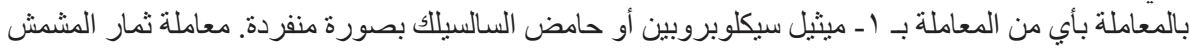

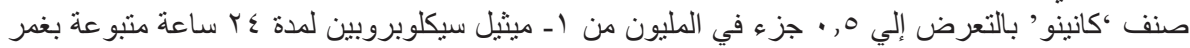

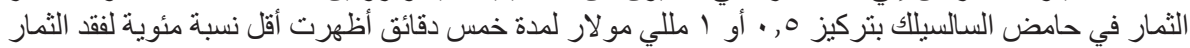

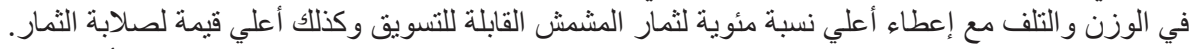

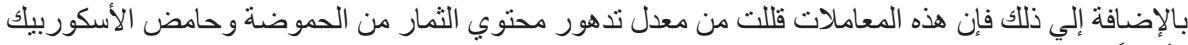

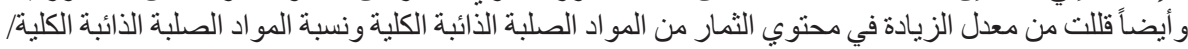

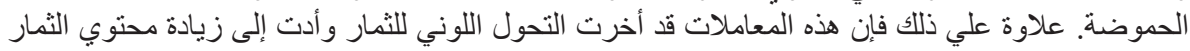

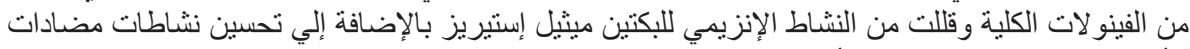

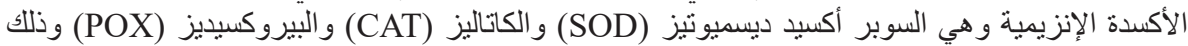
مقارنة بثمار المشمش المعاملة بالمعاملات الأخرى و غير المبر (لمعاملة (الكنترول).
\end{abstract}

